\title{
Poznajmy piękno kamieniarki kolegiaty p.w. Narodzenia Najświętszej Maryi Panny w Tarnowie
} Let us see the beauty of masonry in the Birth of Holy Virgin Mary collegiate in Tarnów

\author{
Anna Lannik, Anna Smoleńska, Bernadeta Wójcik \\ Katedra Geologii Złożowej i Górniczej, Wydzial Geologii, Geofizyki i Ochrony Środowiska, \\ Akademia Górniczo-Hutnicza, al. Mickiewicza 30, 30-059 Kraków; \\ e-mail:lanan@interia.pl; smolensk@geol.agh.edu.pl; bernadeta.wojcik@gmail.com
}
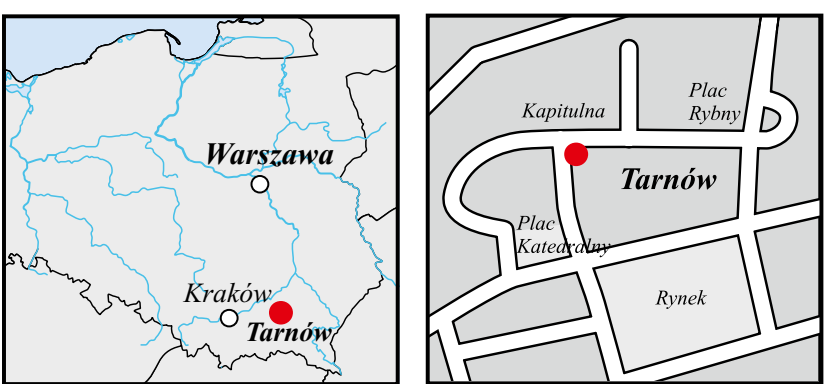

Treść: Głównym celem niniejszego artykułu jest promocja gotyckiej katedry w Tarnowie wśród turystów interesujacych się kamieniem i jego walorami dekoracyjnymi. Wprowadzono czytelnika $w$ architekture gotyckq szczegółowo omówionq na przykładzie katedry. Szczególnq uwage zwrócono na rodzaje i pochodzenie skat, które licznie zostaty zastosowane do ozdoby murów zewnętrznych oraz wnętrza kościoła.

Słowa kluczowe: gotyk, Tarnów, kolegiata, kamień

Abstract: Promotion of the Gothic cathedral in Tarnów among the tourists interested in rocks and their decorative values is the major aim of this paper. A reader has got introduced to the Gothic architecture discussed in details at the example of the cathedral. A particular attention has been paid to the variety of types and provenance of stones used in constructing and ornamenting the outer walls and the interior of the church.

Key words: Gothic, Tarnów collegiate, stone

\section{Wstęp}

Góra Św. Marcina nierozerwalnie wiąże się z początkiem histotii Tarnowa. To tu w IX wieku stanęło, jedno z największych w średniowiecznej Polsce, grodzisko o powierzchni prawie 10 hektarów. Przez wieki należało do królów lub książąt, którzy mieli różny wpływ na jego dzieje i rozwój.

Tarnów powstał w ostatnich latach panowania króla Władysława Łokietka dzięki inicjatywom osadniczym protoplasty rodu Leliwitów Tarnowskich, Spycimira wojewody krakowskiego. Dzięki niemu 7 marca 1330 roku miasto otrzymało prawa miejskie z rąk króla. Kościół Narodzenia Najświętszej Maryi Panny należał do jednej z trzech parafii, których świątynie zbudowano przed 1400 rokiem. Dnia 17 kwietnia 1400 roku biskup krakowski Piotr Wysz, na prośbę Jana z Tarnowa, wnuka Spicymira, podniósł kościół parafialny w rynku do godności kolegiaty (Ginalska, 2001).

Obecnie Tarnów jest największym po Krakowie ośrodkiem miejskim województwa małopolskiego. Najatrakcyjniejszą część miasta stanowi śródmieście. Znajduje się tu kilkadzie- siąt zabytkowych obiektów z epoki gotyku, renesansu i baroku. Jednym z najpiękniejszych z nich jest gotycka kolegiata p.w. Narodzenia Najświętszej Maryi Panny usytuowana na Placu Katedralnym (Fig. 1).

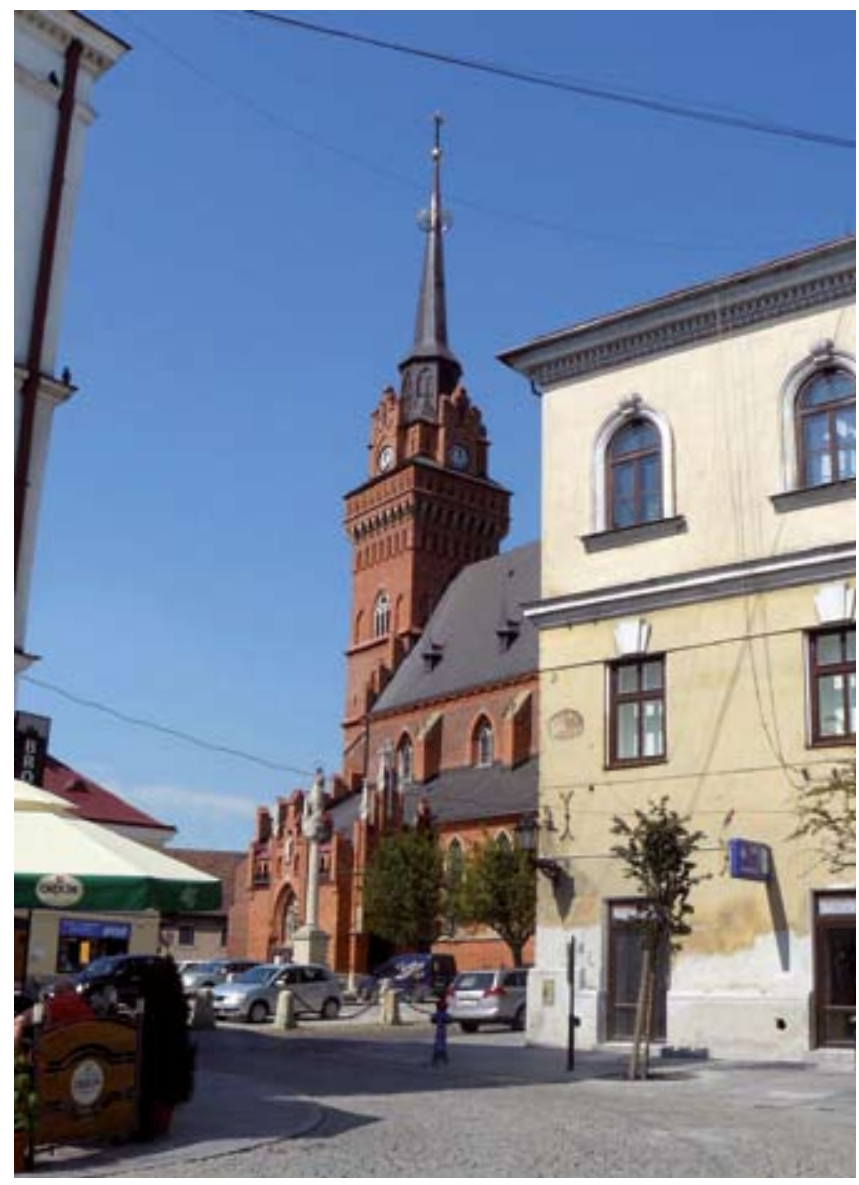

Fig. 1. Widok Kolegiaty od strony południowo-wschodniej, fot. B. Wójcik - A south-west view of the Cathedral, phot. B. Wójcik

\section{O kolegiacie słów kilka}

Kolegiata p.w. Narodzenia Najświętszej Maryi Panny, jak wszystkie budowle gotyckie odznacza się dużą lekkością. Zbudowana jest z cegły, a dekoracyjna kamieniarka zdobi okna i wejścia. Okna wypełnione są pięknymi witrażami, a strzeliste wieże nadają jej smukłości. Skonstruowana została na planie podłużnym, jako świątynia orientowana, trzynawowa, z wydłużonym prezbiterium zamkniętym trójboczną absydą oraz dobudowaną ze strony zachodniej wieżą 
o wysokości 72 m, ozdobioną koroną w 1898 roku. Wnętrza dekorują sklepienia krzyżowo-żebrowe i system łuków przyporowych, odciążających ściany budowli.

W Katedrze znajdują się wspaniałe rzeźby z przełomu gotyku i renesansu, późnogotyckie stalle, skarbiec, zespół późnogotycko-renesansowych kanonii, kamienne portale i pomniki nagrobne. Do kościoła (Fig. 2) można udać się z przedsionka południowego (1), zachodniego (7) i północnego (14), a do zakrystii jest osobne wejście (15).

Przedsionek południowy prowadzi do południowej nawy. Powstała ona w połowie XIX wieku z połączenia szeregu kaplic (od zachodu): Rozesłania Apostołów (2), kruchty Św. Krzyża (3), Matki Bożej Szkaplerznej (4), św. Benedykta (5) i Najświętszego Sakramentu (6) dobudowywanych od XV wieku do głównej części Katedry (Fig. 2). W nawie południowej znajdują się dwa ołtarze: Najświętszego Sakramentu oraz Matki Bożej Bolesnej. Na uwagę zasługują również grobowce księcia Eustachego Sanguszki i księdza Marcina Łyczki, tablice pamiątkowe oraz sklepienia (Fig. 2).

Przedsionek północny prowadzi do nawy północnej, powstałej około 1850 roku przez połączenie w jedną całość kaplic (od zachodu): św. Anny (10), kruchty (11) i św. Relikwii (12). W omawianej nawie znajdują się także grobowce księdza Kaspra Branickiego i Trzech Janów oraz tablice pamiątkowe (Fig. 2).

Przedsionek zachodni (7), pochodzący z XV wieku oraz wejście przez zakrystię (13) prowadzą do nawy głównej (8), najstarszej części Katedry (Fig. 2). Oddzielają ją arkady ostrołukowe od naw bocznych. Podwyższone prezbiterium z ołtarzem głównym (9) oddzielone jest od części dla wiernych ostrym łukiem, natomiast w przęśle zachodnim znajduje się chór organowy oparty na trzech neogotyckich arkach (Hry-
cow-Buczyńska, 1991). Prezbiterium powstawało stopniowo w wieku XV i XIX. W dobudowanej części prezbiterium znajdują się stalle kanonickie oraz wykonane w 1892 roku kamienne figury polskich świętych: św. Kazimierza, św. Kingi, św. Wojciecha, św. Stanisława ze Szczepanowa, bł. Szymona z Lipnicy i św. Jana Kantego. Ozdobą ołtarza głównego są cztery kamienne pomniki grobowe, będące dziełami sztuki o wielkim znaczeniu dla dziejów kultury polskiego renesansu i manieryzmu: Tarnowskich, Zofii z Tarnowskich księżnej Ostrogskiej, Ostrogskich i Barbary z Rożnowa. W centralnej części ołtarza stoi kamienny stół ofiarny oraz ambona.

Do budowy Katedry użyto różnych materiałów budowlanych. Wśród nich obok cegły powszechnie stosowano skały pochodzące najczęściej ze złóż polskich, w mniejszym udziale zastosowano kamień zagraniczny.

\section{Kamień na zewnątrz Kolegiaty}

Stojąc na Placu Katedralnym można podziwiać na zewnątrz kościoła piaskowiec w cokole i obramieniach okiennych oraz wapień, z którego wykonane są detale architektoniczne, takie jak: pinakle, rozety, a także piękny portal przedsionka zachodniego (Fig. 3).

Cokół katedry do wysokości 0,95 m obłożony jest płytami piaskowcowymi, które zamontowane są na sworzniach. Płyty o różnych rozmiarach są ułożone w dwóch rzędach. $\mathrm{W}$ górnym są one najmniejsze i zaokrąglone, co nadaje okładzinie lekkości.

Piaskowiec zastosowany w płytach cokołowych ma barwę szaro-kremową z rdzawymi plamkami, miejscami żółtą, strukturę zbitą i bezładną, a teksturę drobnoziarnistą, prze-

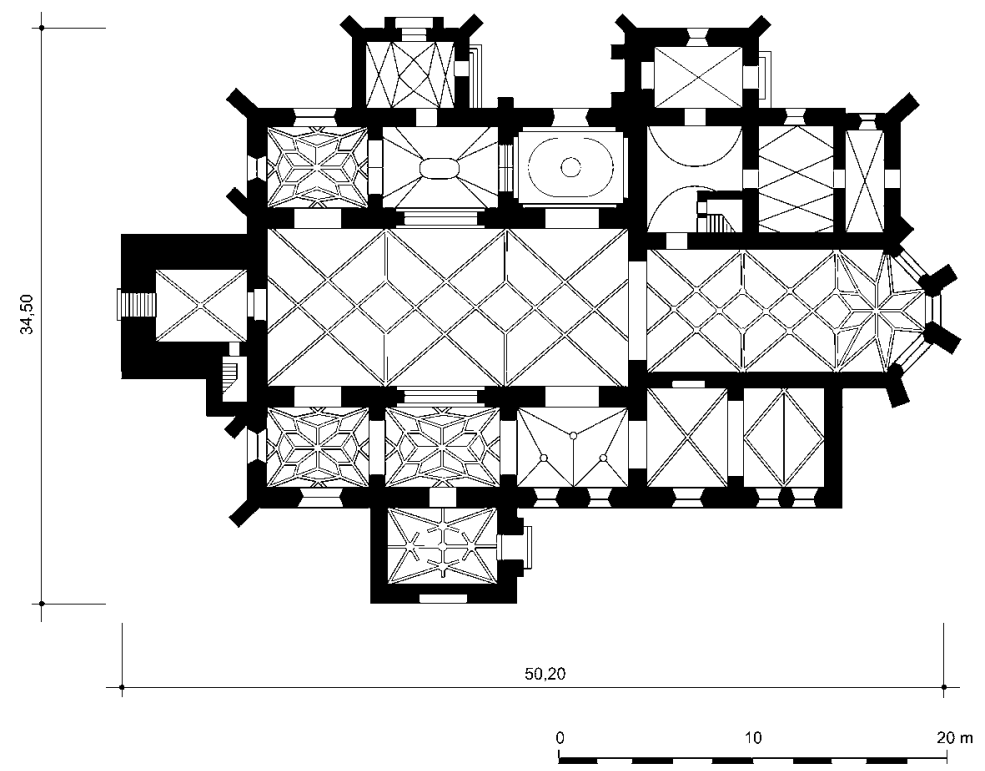

Fig. 2. Plan sytuacyjny Katedry (Hrycow-Buczyńska, 1991): 1 - przedsionek południowy, Nawa południowa: 2 - kaplica Rozesłania Apostołów, 3 - kruchta Św. Krzyża, 4 - kaplica Matki Bożej Szkaplerznej, 5 - kaplica św. Benedykta, 6 - ołtarz Najświętszego Sakramentu, 7 - kruchta pod wieżą (przedsionek zachodni), 8-nawa główna, 9-ołtarz i prezbiterium; Nawa północna: 10 - kaplica św. Anny, 11 - kruchta, 12 - kaplica św. Relikwii, 13 - zakrystia, 14 - przedsionek północny, 15 - wejście do zakrystii • The plan of the Cathedral (Hrycow-Buczyńska, 1991): 1 - southern porch, southern aisle: 2 - Chapel of the Sending of Apostles, 3 - Chapel of the Holy Cross, 4 - Chapel of Our Lady of the Scapular, 5 - Chapel of St. Benedict, 6 - altar of the Holy Sacrament, 7 - narthex under the tower (western porch), 8 - nave, 9 - high altar and chancel; northern aisle: 10 - Chapel of St. Anne, 11 - narthex, 12 - Chapel of the Holy Relics, 13 - vestry, 14 - northern porch, 15 - entrance to the vestry 


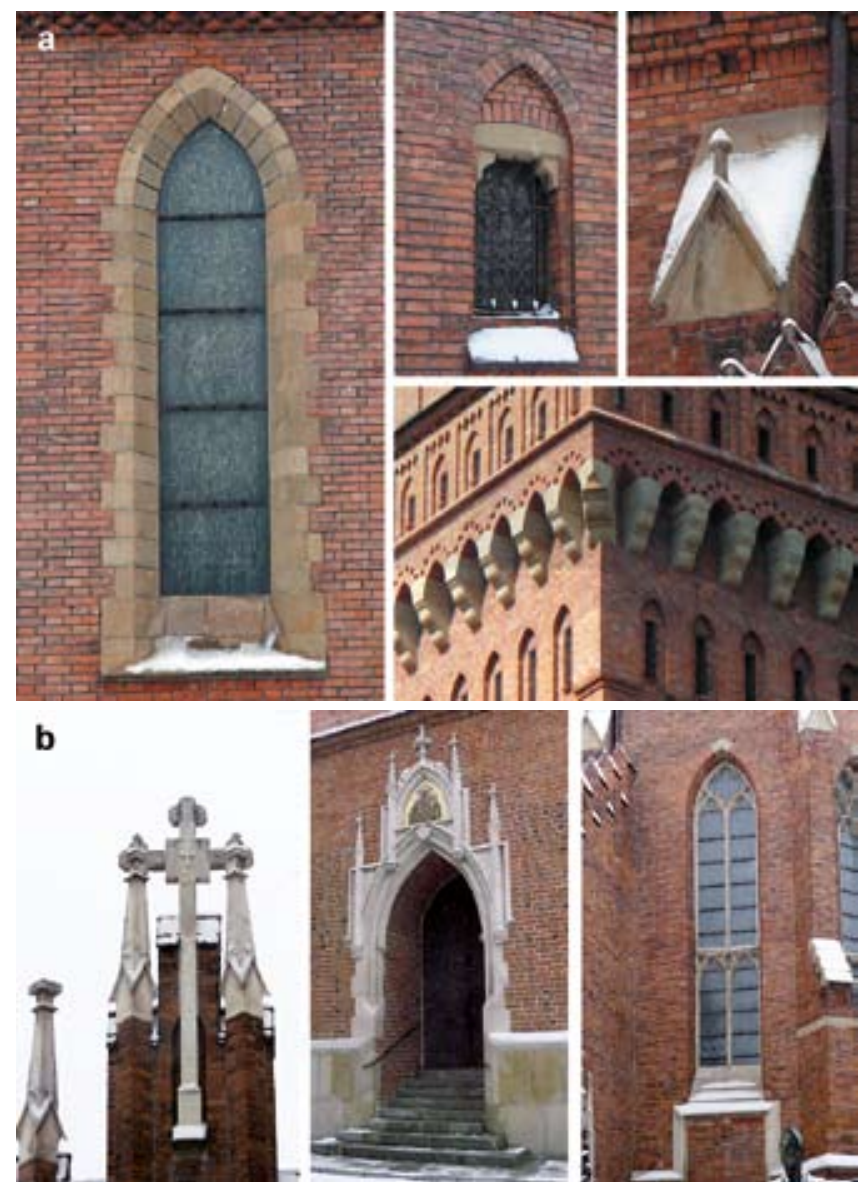

Fig. 3. Elementy dekoracyjne wykonane z piaskowca istebniańskiego (a) i wapienia pińczowskiego (b) w Katedrze, fot. B. Wójcik • Decorative elements made of the Istebna sandstone (a) and the Pińczów limestone (b), phot. B. Wójcik).

chodzącą w nierównoziarnistą. W celu uzyskania lepszego wyglądu dekoracyjnego nadano mu groszkowaną fakturę kamieniarską. Ocena makroskopowa i mikroskopowa wskazuje, że jest to piaskowiec istebniański. Skała ta tworzy liczne wychodnie ciągnące się szerokim pasem od okolic Wisły i Istebnej przez rejon Wadowic, Myślenic, Dobczyc, Brzeska aż po okolice Sanoka i Nowego Sącza (Peszat, Buczek-Pułka, 1984). W profilu warstwy istebniańskie są dwudzielne, z czego dolna część ma największe znaczenie architektoniczne. Występują bowiem w grubych ławicach, dochodzących nawet do 5 metrów miąższości, co umożliwia pozyskanie dużych bloków. Są silnie porowate, mało nasiąkliwe, o małej lub średniej wytrzymałości na ściskanie i bardzo dobrej mrozoodporności (Bromowicz, 2001). Piaskowce istebniańskie na terenie Karpat były eksploatowane w licznych kamieniołomach i stosowane powszechnie w wielu budowlach różnych miast. Wychodnie tych warstw najbliżej Tarnowa znajdują się na Pogórzu Wiśnicko-Rożnowskim (Skoczylas-Ciszewska, Kamieński, 1959). Były one eksploatowane między innymi w Gromniku i Sobolowie, a w tym ostatnim pozyskiwane są nadal. Z uwagi na bliskie położenie kamieniołomów względem Tarnowa należy wnosić, że piaskowiec stosowany w starych budowlach miasta, a więc i w Katedrze, pochodził najprawdopodobniej z tych złóż.

Wapień zastosowany w dekoracyjnych elementach architektonicznych na świeżym przełamie ma barwę jasnobeżową, a na powierzchni zwietrzałej jasnoszarą. Jest bardzo porowaty i drobnodetrytyczny. Biorąc pod uwagę wygląd i formę wykorzystania można stwierdzić, że jest to wapień pińczowski. Jego nazwa pochodzi od miejsca wydobycia - Pińczowa, miasteczka położnego na lewym brzegu Nidy w województwie świętokrzyskim. Kamień ten występuje w złożu w grubych blocznych ławicach (Bromowicz, 2001). Jego cechą charakterystyczną jest tekstura różnodetrytyczna, zawierająca fragmenty mniej lub bardziej pokruszonych organizmów, takich jak: mszywioły, ślimaki, małże, korale, jeżowce oraz glony z rodzaju Lithothamnia, od których wywodzi się nazwa tej skały - wapień litotamniowy. Oprócz tych składników wapień zawiera ziarna kwarcu frakcji piaskowej oraz substancję ilastą. Wszystkie składniki łączy skąpe spoiwo węglanowe. Przeważnie występuje ono na kontaktach ziarn, co powoduje dużą porowatość tych wapieni. Dużym walorem wapienia pińczowskiego jest jego utwardzenie po wyjęciu ze złoża przez utratę wilgoci skalnej, która może wynosić nawet 17\% (Kozłowski, 1986). Zachodzi wówczas proces wytrącania i krystalizacji rozproszonego w skale węglanu wapnia, co doprowadza do utwardzenia powierzchni wydobytej skały lub elementu wyrzeźbionego. Kolejnym walorem tej skały jest jej niewielki ciężar objętościowy, który wynosi średnio $1,7 \mathrm{~g} / \mathrm{cm}^{3}$ przy wahaniach 1,5-2,0 g/ $\mathrm{cm}^{3}$ (Bromowicz, 2001). Dzięki temu skała ta chętnie stosowana była w sklepieniach kopuł, czy w dekoracjach rozetowych okien w gotyku i renesansie. Ponadto duża (29-37\%) porowatość wapienia (Bromowicz, 2001) wpływa na złą przewodność ciepła co sprawia, że jest doskonałym materiałem budowlanym. Jego współczynnik przewodności cieplnej jest niższy niż cegły (Rajchel, 2004). Mrozoodporność jest oceniana od dobrej (Penkala, 1986) do słabej (Bromowicz, 2001). Skała ta jest zatem łatwa w obróbce, a bez względu na jej charakter ma zawsze fakturę matową, ziemistą. Niezwykłe walory wapienia pińczowskiego doceniono już w średniowieczu i wielu architektów stosowało go od XI wieku w Krakowie (Rajchel, 2004), jak też w innych miastach Polski. Również w Katedrze tarnowskiej skała ta została wykorzystana do dekoracji zewnętrznej.

Wizerunek Pana Jezusa Ukrzyżowanego umieszczony na wschodniej ścianie katedry, obramowany jest wapieniem pińczowskim. $Z$ niego wykonane są też pinakle, będące charakterystycznymi elementami architektury gotyckiej. Są to smukłe czworoboczne wieżyczki zwieńczone kwiatonem, a zakończone ostrosłupem, którego krawędzie dekorowane są żabkami.

Kolejną skałą zastosowaną na zewnątrz Katedry jest granit ze Strzegomia. Z niego wykonane są schody prowadzące do trzech wejść kościoła. Jest to odmiennie wykształcona skała niż wcześniej opisywane. Należy do utworów magmowych głębinowych. Stąd jej struktura jest masywna, a składniki są w pełni wykrystalizowane i dobrze widoczne. Są to kwarc i skaleń, głównie ortoklaz o przeciętnych średnicach 3-8 $\mathrm{mm}$ oraz biotyt 2-4 $\mathrm{mm}$. Granit należy do skał, które doskonale przyjmują i zachowują poler. Na takich powierzchniach kontury poszczególnych składników są wyraźniej widoczne niż na naturalnym przełamie, dlatego wypolerowany granit wygląda niezwykle atrakcyjnie. Monotonną fakturę skały urozmaicają ksenolity, określane popularnie 
„myszkami”. Są to nagromadzenia ciemnych minerałów, takich jak biotyt i horblenda, które tworzą różnej wielkości skupiska względnie smugi zwane szlirami. Z tych względów skała ta ma szerokie zastosowanie w budownictwie jako kamień architektoniczny. Ponadto występujący w granicie cios termiczny w trzech prostopadłych płaszczyznach ułatwia eksploatację bloków, które dalej cięte są na płyty o różnym zastosowaniu: chodnikowe, okładzinowe i posadzkowe, czy nagrobkowe.

Na zewnątrz Katedry granit zastosowano w postaci płyt, którymi obłożono stopnie. Płyty poziome, czyli stopnice mają fakturę płomieniowaną, antypoślizgową, natomiast pionowe - podstopnice są polerowane. Na ich powierzchniach widoczne są wyraźne kryształy popielatego lub dymnego kwarcu, białego ortoklazu oraz drobne blaszki czarnego biotytu.

\section{Kamień wewnątrz Kolegiaty}

Wewnątrz Kolegiaty zastosowano w wielu miejscach różne odmiany skał, które zdobią świątynię i niezwykle podnoszą jej walory architektoniczne.

\section{Przedsionek południowy}

W Katedrze najbardziej uczęszczany jest przedsionek południowy, w którym z kamienia wykonane są: portal, posadzka, próg, kropielnica oraz tablice pamiątkowe (Fig. 4).

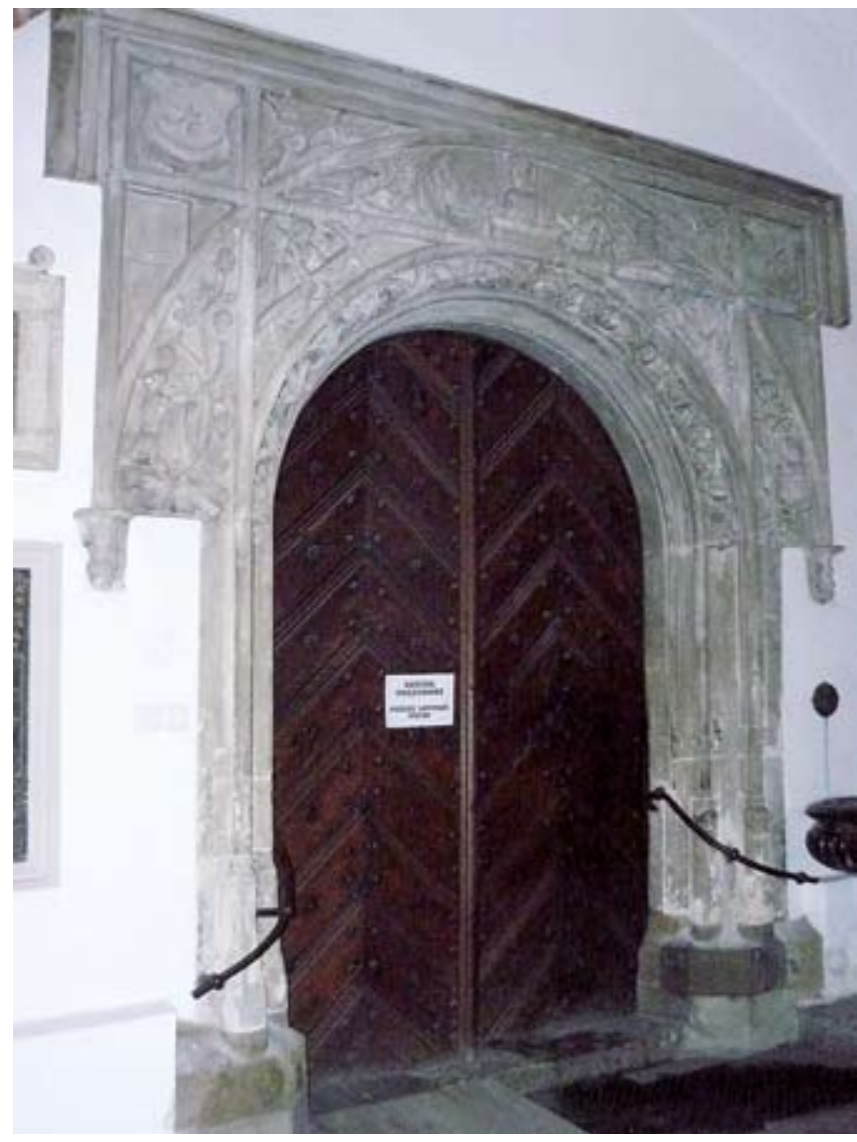

Fig. 4. Portal wykonany z wapienia pińczowskiego, kropielnica $\mathrm{z}$ marmuru dębnickiego oraz granitowa posadzka w przedsionku południowych Katedry, fot. B. Wójcik - The portal made of the Pińczów limestone, holy-water basin made of the Dębnik marble, and the granite floor in the southern porch, phot. B. Wójcik

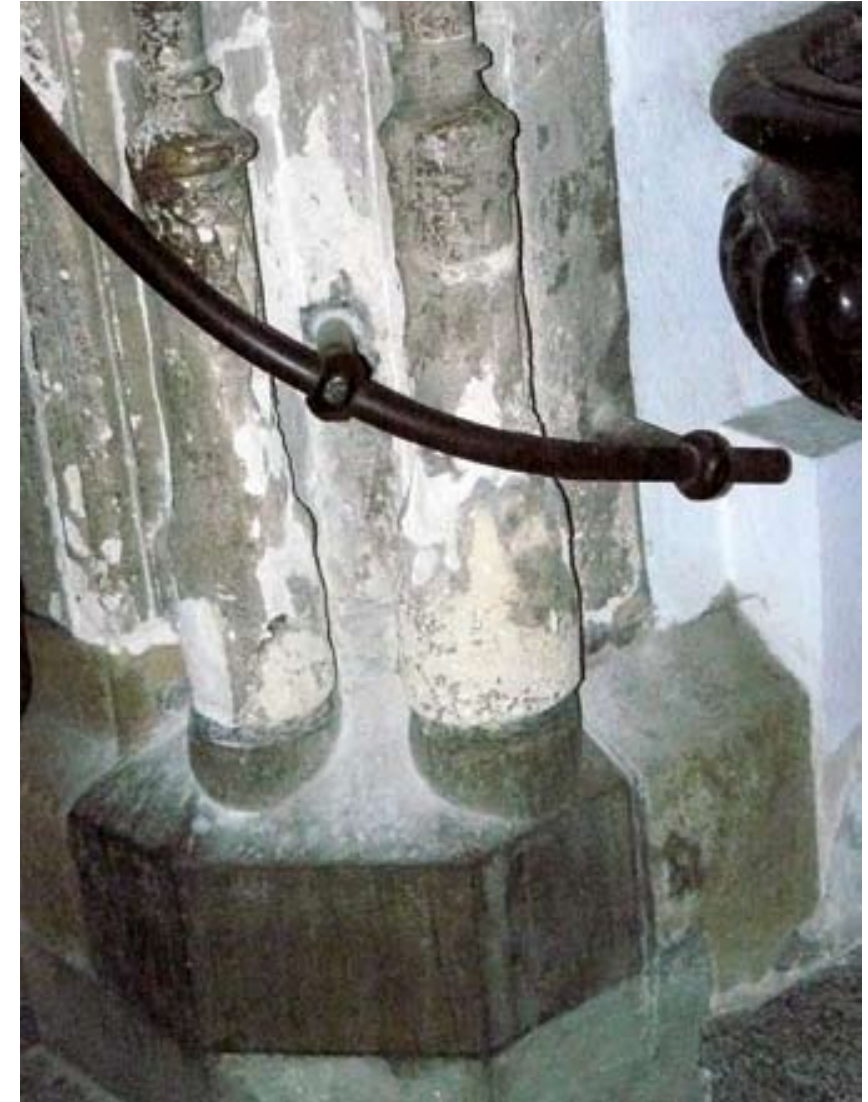

Fig. 5. Liczne ubytki w wapieniu pińczowskim w dolnych częściach portalu, fot. B. Wójcik • Numerous losses of the Pińczów limestone in lower parts of a portal, phot. B. Wójcik

Materiał kamienny pochodzi tylko z polskich złóż. Użyto tu zatem następujących skał osadowych: piaskowca istebniańskiego, wapienia pińczowskiego, polerujących się wapieni zbitych z Dębnika i Morawicy oraz skały magmowej - granitu ze Strzegomia.

Portal, pochodzący z 1511 roku, wykonano z wapienia pińczowskiego w stylu gotycko-renesansowym i osadzono na cokole $\mathrm{z}$ piaskowca istebniańskiego. Zamknięty jest on półkoliście $\mathrm{z}$ oryginalnym obramieniem, z laskowaniami, gałązkami i wstęgami oraz bogatą dekoracją rzeźbiarską (Hrycow-Buczyńska, 1991). Wapień pińczowski i piaskowiec istebniański są podobnie wykształcone do opisywanych na zewnątrz kościoła. Jednak stan ich zachowania we wnętrzu jest gorszy co świadczy, że dawno nie były konserwowane. W dolnej części portalu obserwuje się ubytki w wapieniu i zabrudzenia pyłowe, natomiast w części górnej występują tylko te drugie. Ubytki w kamieniu są wynikiem działalności człowieka i zmian temperatury, bowiem portal znajduje się blisko drzwi wejściowych (Fig. 5). Woda nanoszona do przedsionka w dni deszczowe powoduje, że w wyniku podciągania kapilarnego wapień w dolnej części portalu jest często zawilgocony. Ułatwia to przyklejanie się zanieczyszczeń, stąd są obecne w tym miejscu zabrudzenia. Ponadto wapień ma niższą wytrzymałość i jest bardziej podatny na uderzenia i wykruszanie się składników. Dlatego w tej części portal ma liczne ubytki co obniża jego dekoracyjność.

Posadzkę w przedsionku południowym zdobi ten sam granit strzegomski, który został zastosowany na schodach wejściowych. Występuje tu w formie płyt o fakturze półpo- 
lerowanej. Próg przy portalu wykonany jest natomiast $\mathrm{z}$ wapienia dewońskiego. Jest to niezwykle popularny kamień dekoracyjny, który daje się szlifować i polerować, jednak pod wpływem warunków atmosferycznych traci poler. Określany jest marketingowo „marmurem”. Występuje w wielu miejscach Gór Świętokrzyskich, od Miedzianki na zachodzie po Żurawniki na wschodzie (Czermiński, 1960). Do najbardziej znanych miejsc eksploatacji należą kamieniołomy: Bolechowice, Szewce i Jaźwica. Wapienie te występują najczęściej w grubych ławicach pozwalających pozyskiwać bloki, które są cennym surowcem do wyrobu płyt okładzinowych i posadzkowych, parapetów czy kominków. Po wypolerowaniu skała ta oprócz pięknej barwy, jasnobrunatnej i ciemnobrunatnej z odcieniem fioletowym, ujawnia bogactwo form organicznych. Największą dekoracyjność wykazują Stromatopora sp., ukształtowane w formie bulastych, wielopowłokowych osobników oraz gałązkowate Amphipora sp. Ponadto występują inne skamieniałości: małże, ślimaki czy korale. Piękno wapienia podkreślają również nieregularnie przebiegające żyłki białego i różowego kalcytu. Wapień zastosowany w progu Katedry miał fakturę polerowaną, którą z czasem stracił ze względu na ciągłe użytkowanie. Stąd walory dekoracyjne tego kamienia są słabo widoczne.

Na uwagę zasługuje również barokowa kropielnica z XVII wieku (Hrycow-Buczyńska, 1991) wykonana z „marmuru” dębnickiego o głębokiej czarnej barwie (Fig. 6a). Z petrograficznego punktu widzenia skała ta, podobnie jak wcześniej omawiany wapień, należy do grupy skał osadowych. Jej charakterystycznym elementem dekoracyjnym jest barwa zmieniająca się od czarnej do popielatej, jednolita lub tworząca nieregularne plamiste bądź chmurowe desenie. Związane jest to ze zmienną strukturą wapienia, która bywa zbita, bulasta, gruzłowata lub falista (Bednarczyk, Hoffman, 1989). Czarna barwa wapienia związana jest z obecnością rozproszonego, bardzo drobnoziarnistego pirytu, częściowo przetworzonego na siarkowodór, objawiającego się charakterystycznym zapachem (Łaptaś, 1982, 1989; Bednarczyk, Hoffman, 1989). Ta rzadko spotykana barwa jest jednak nietrwała, bowiem wapień traci ją pod wpływem działania czynników atmosferycznych. Stąd może być stosowany jedynie do wystroju wnętrz. Dekoracyjność „marmuru” dębnickiego podkreślają również szczątki organiczne takie jak: Amphipora sp., korale, fragmenty liliowców, ramienionogi i ślimaki, a przede wszystkim białe żyłki kalcytowe, nieregularnie w nim rozmieszczone. Skała ta występuje w dwóch odmianach: gruzłowatej oraz jednorodnej mikrytowej.

„Marmur” dębnicki odmiany jednorodnej mikrytowej został użyty ponadto do wykonania chrzcielnicy z XVII wieku oraz tablic pamiątkowych (Fig. 6 b, c, d). Jest on niezwykle dekoracyjny dzięki licznym białym żyłkom kalcytowym, które bezładnie rozrzucone w kamieniu doskonale odznaczają się w czarnym tle. Pomimo swych walorów dekoracyjnych osłabiają kamień, który w tych miejscach jest bardziej podatny na spękania i tworzenie się ubytków.

Każda rzeźba w Katedrze wykonana jest z pojedynczych bloków „marmuru” dębnickiego. Rozmiary takie jak wysokość i średnica misy, wynoszące odpowiednio dla kropielnicy $0,9 \mathrm{~m}$ i 0,75 m, a dla chrzcielnicy $1,2 \mathrm{~m}$ i 0,65 m, świadczą o wielkości bloków, które najczęściej wydobywane były
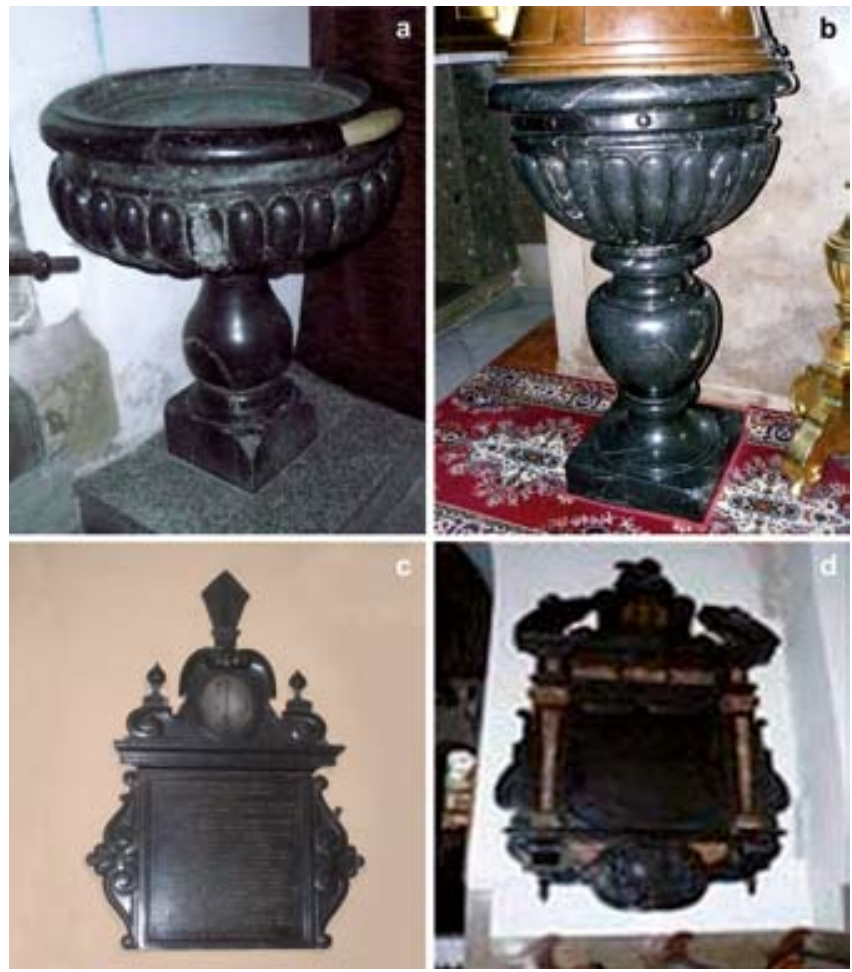

Fig. 6. Kropielnica (a) i chrzcielnica (b) oraz tablice pamiątkowe (c, d) wykonane $z$ jednorodnego mikrytowego wapienia dębnickiego, fot. B. Wójcik - The holy-water basin (a) and the font (b) made of the homogenous, micritic Dębnik limestone, photo by B. Wójcik

w złożu i poddawane dalszej obróbce. Chrzcielnica jest lepiej zachowana w porównaniu z kropielnicą, gdyż znajduje się wewnątrz kościoła. Powierzchnia jej nadal jest wypolerowana w przeciwieństwie do powierzchni kropielnicy, która jest zmatowiała, a niektóre dekoracyjne jej uwypuklenia sa jasnopopielate. Wynika to z usytuowania kropielnicy w przedsionku Katedry, gdzie mają na nią wpływ czynniki atmosferyczne.

Stan zachowania tablic pamiątkowych jest zróżnicowany. Powierzchnie płaskie mają nadal czarną barwę. W miejscach wypukłych wapień jest natomiast zmatowiały i barwy popielatej.

\section{Nawa południowa}

Nawę południową zdobią przede wszystkim marmury włoskie, natomiast w mniejszym stopniu wykorzystano tu polskie wapienie zwięzłe. Jest ona bardzo jasna, co związane jest głównie z białą barwą występującego tu jurajskiego marmuru kararyjskiego Bianco Carrara Unito C, pochodzącego z Toskanii. Biel zaburzona jest występującymi gdzieniegdzie szarymi żyłkami, bezładnie rozrzuconymi w kamieniu. Stanowią one element dekoracyjny tej skały. Marmur jest bardzo drobnokrystaliczny, co wpływa na jego wysoką (130 MPa) wytrzymałość na ściskanie. Stąd przyjmuje poler, który jeszcze bardziej podnosi jego walory dekoracyjne (ICONS, 2006).

Marmur kararyjski był ulubionym materiałem rzeźbiarskim Michała Anioła i od wieków należy do skał chętnie stosowanych w obiektach sakralnych. W nawie południowej został zastosowany w 1900 roku przez Tadeusza Błotnickiego 

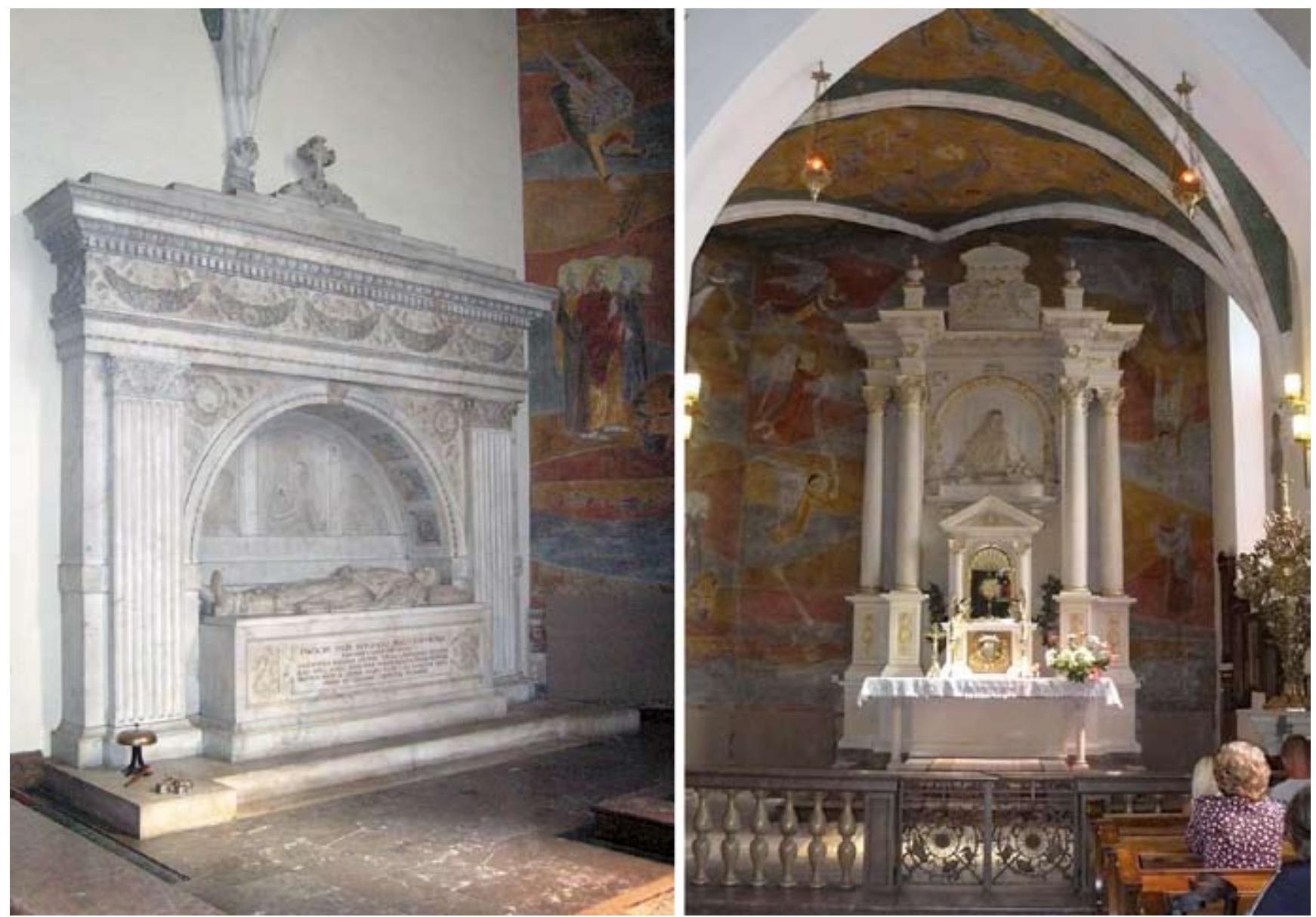

Fig. 7. Grobowiec księcia Sanguszko (a) i ołtarz (b) w nawie południowej Katedry wykonane z marmuru kararyjskiego, fot. B. Wójcik • The tomb of prince Sanguszko (a) and the altar in the southern aisle made of the Carrara marble, phot. B. Wójcik

do wystroju neorenesansowego ołtarza Najświętszego Sakramentu oraz grobowca księcia Sanguszko (Fig. 7).

Posadzkę w części ołtarza południowego oraz balustradę zdobi wapień o barwie i skamieniałościach charakterystycznych dla wapienia dewońskiego (Fig. 8). Jego wypolerowana powierzchnia daje znakomitą okazję do obserwacji fauny, czego przykładem są gałązkowate amfipory oraz stromatopory występujące $\mathrm{w}$ formie wielopowłokowych kolonii (Fig. 8b). Widoczne są również nieregularne żyłki białego i różowego kalcytu. Tralki natomiast wytoczone są z jasnokremowego wapienia morawickiego, charakteryzującego się mikrytową teksturą, licznymi ciemniejszymi od tła plamkami, tzw. tuberoidami (fragmenty gąbek), szwami stylolitowymi oraz fauną, głównie amonitów i belemnitów. Rzadziej spotykane są ramienionogi, igły gąbek czy fragmenty jeżowców. Wapień ten wieku jurajskiego należy do „marmurów” kieleckich. Jako materiał bloczny wydobywany jest w Morawicy i Woli Morawickiej (Peszat, 1964). Uznawany jest za jeden z ciekawszych surowców architektonicznych i używany jest powszechnie w formie polerowanej do wykończenia wnętrz.

W kaplicy Matki Bożej Szkaplerznej znajduje się późnorenesansowy pomnik nagrobny księdza Marcina Łyczki (Fig. 9) zaprojektowany prawdopodobnie przez Wojciecha Kuszyca, a w kaplicy Rozesłania Apostołów renesansowy pomnik Barbary z Tęczyńskich Tarnowskiej (najbliżej głównego wejścia), autorstwa prawdopodobnie Jana Marii Padovano (Hrycow-Buczyńska, 1991). Oba grobowce wyrzeźbione zostały w drobnodetrytycznym wapieniu pińczowskim, barwy jasnoszarej. Postacie zmarłych wykonano najprawdopodobniej z marmuru włoskiego Rosso di Verona o charakterystycznej ciemnoczerwonej barwie oraz obłych kontrastowych gruzłach, wyraźnie odznaczających się od marglistożelazistego spoiwa. Kamień ten należy do grupy czerwonych marmurów, które znane były na terenie Węgier w Esztergom i Szekesfeherwar już w 1198 roku (Procyk, 1998). Wszystkie te skały były chętnie używane jako materiał rzeźbiarski przez wspaniałych renesansowych artystów między innymi Franciszka Florentczyka i Bartłomieja Berrecci'ego, pomimo iż są oporne w obróbce i łatwo ulegają rozkruszeniu ze względu na niejednorodną budowę. Marmur włoski Rosso di Verona w stosunku do wspomnianych marmurów węgierskich, posiada intensywniejszą czerwoną barwę gruzłów wapiennych, które są bardziej zwięzłe, mikrytowe w stosunku do marglisto-żelazistego tła. Gruzły mają zróżnicowaną wielkość i ostro odgraniczają się od tła, choć miejscami są niewyraźne. Marmur ten został zastosowany w Krakowie na Wawelu w sarkofagu Władysława Jagiełły (Bromowicz, Magiera, 2006).

Elementy dekoracyjne i konstrukcyjne sklepień wykonano z dolnojurajskiego piaskowca o charakterystycznej jednorodnej białej lub jasnokremowej barwie. Piaskowiec ten wydobywany jest głównie w północno-zachodnim i północnowschodnim obrzeżeniu Gór Świętokrzyskich. Znany jest pod nazwą piaskowców szydłowieckich i kunowskich, które były 

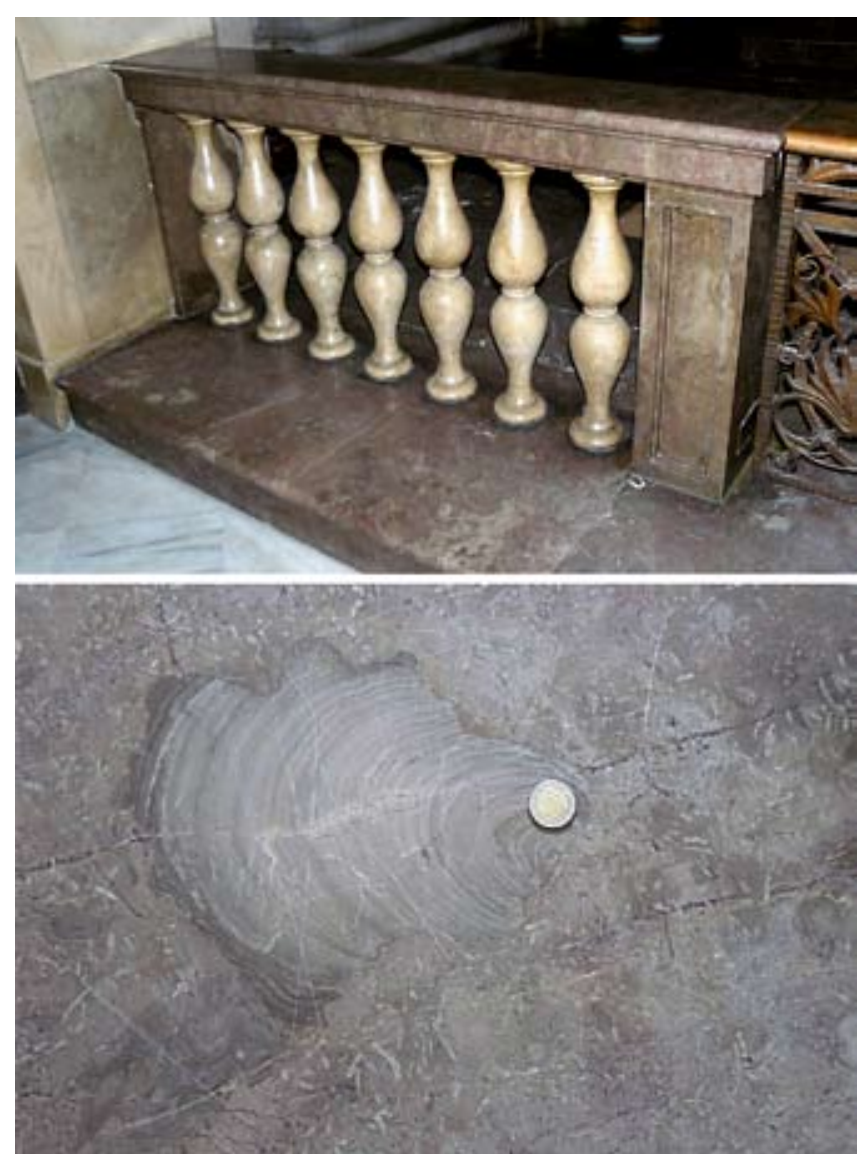

Fig. 8. Balustrada z tralkami i posadzka w części ołtarzowej nawy południowej wykonane $\mathrm{z}$ wapieni kieleckich (a), gałązkowate amfipory oraz kuliste duże stromatopory (b), fot. B. Wójcik - The railing with banisters and the floor made of Kielce limestone (a) in the altar part of the southern aisle; twig-like amphipora and large, spherical stromatopora (b), phot. B. Wójcik

i dalej są eksploatowane na potrzeby architektoniczne. Ich cechą charakterystyczną oprócz barwy jest jednorodne drobne uziarnienie i łatwość w obróbce. Podobnie jak wapień pińczowski, twardnieją po wydobyciu ze złoża. $Z$ uwagi na skąpe spoiwo ilasto-krzemionkowe są skałą porowata, łatwo ulegającą ścieraniu. Stąd nie nadają się na płyty chodnikowe czy posadzkowe, natomiast stosowane są do ostrzenia narzędzi oraz jako doskonały materiał rzeźbiarski na finezyjne elementy zdobnicze.

Pod względem konstrukcyjnym sklepienia w południowej nawie Kolegiaty są bardzo zróżnicowane. Wyróżnić można (idąc od zachodu): gwiaździste (1514 r.) wsparte na służkach w narożnikach i zworniku, siedmiopolowe ze wspornikiem (1400 r.), krzyżowo-żebrowe (1514 r.) na wspornikach renesansowych w kształcie głów i neogotyckie. Różnorodność ta jest wynikiem stopniowego dobudowywania kaplic.

\section{Nawa północna}

W ołtarzu nawy północnej, pochodzącym z 1826 roku, podobnie jak w nawie południowej, zastosowano marmur kararyjski Bianco Carrara Unito C (Fig. 10), natomiast posadzkę zdobi wapień z Morawicy, o beżowej barwie, z charakterystycznymi plamkami i szwami stylolitowymi, a także fauną głównie amonitów. Obie skały mają polerowaną fakturę, co jeszcze bardziej uwidacznia ich walory dekoracyjne.

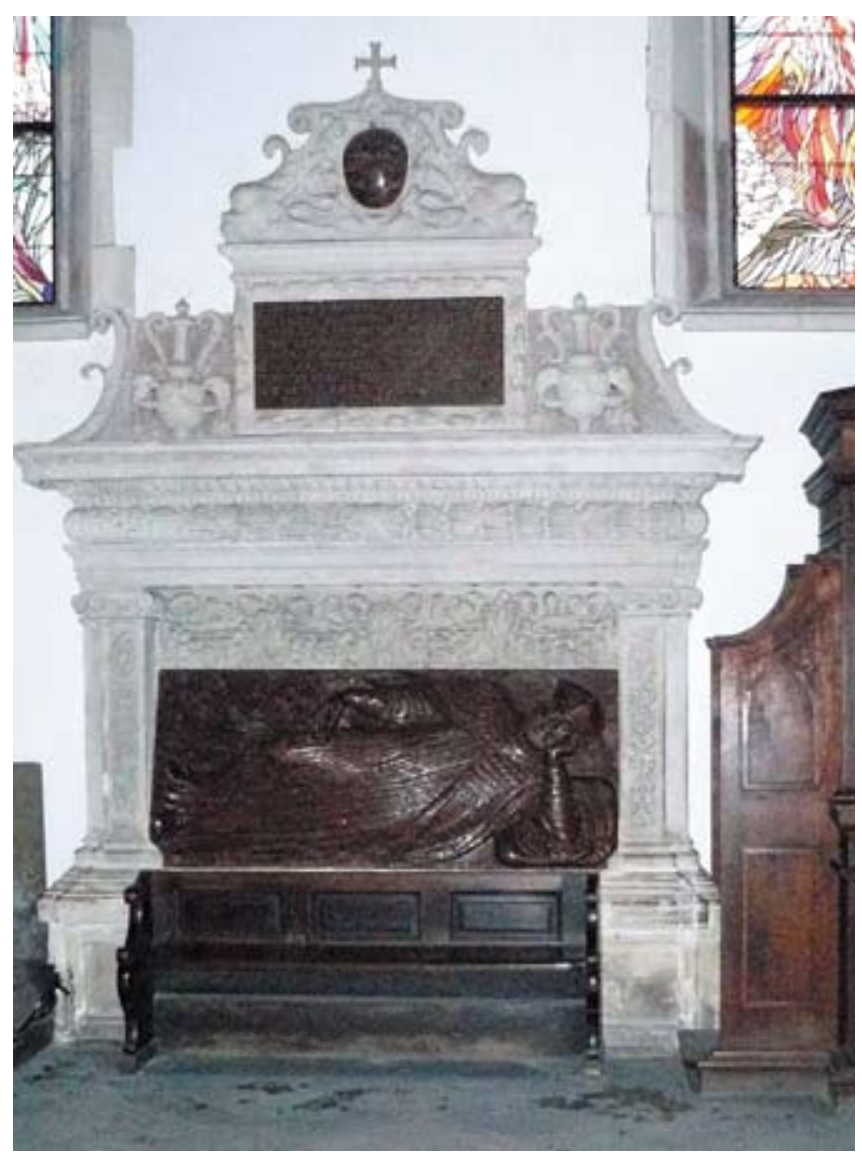

Fig. 9. Grobowiec ks. Marcina Łyczki wykonany z drobnodetrytycznego wapienia pińczowskiego, fot. B. Wójcik - The tomb of priest Marcin Łyczko made of the fine-detrital Pińczów limestone, phot. B. Wójcik

Obok ołtarza mieści się pomnik ks. Kaspra Branickiego (Fig. 11), manierystyczne dzieło rzeźbiarza Santi Gucci'ego (Ginalska, 2001). Wykonano go, podobnie jak nagrobek ks. Marcina Łyczki, z wapienia pińczowskiego i czerwonego marmuru włoskiego.

Renesansowy pomnik Trzech Janów ufundowany został przez Jana Hetmana Tarnowskiego około 1536 roku, aby upamiętnić śmierć najbliższych krewnych: ojca Jana Amora, przyrodniego brata Jana oraz zmarłego w niemowlęctwie synka Jana Aleksandra. Dwaj starsi Tarnowscy przedstawieni sa jako śpiący rycerze $w$ pełnych zbrojach, a figurka zmarłego dziecka ustawiona jest na cokole pomiędzy postaciami dorosłych. Grobowiec znajdujący się w kaplicy św. Anny powstał w wawelskiej pracowni Bartłomieja Berrecci'ego (Fig. 12) z drobnodetretycznego wapienia pińczowskiego, któremu z biegiem czasu osadzające się zanieczyszczenia nadały szarawy odcień.

Tablice pamiątkowe w tej nawie wykonano $z$ kilku rodzajów skał. Jedną z nich reprezentuje czerwony marmur węgierski, obwiedziony ramką z drobnoziarnistego piaskowca szydłowieckiego. Dwie pozostałe tablice wykonano ze wspomnianego już wcześniej mikrytowego wapienia dębnickiego. Faktury wszystkich tablic są polerowane.

Sklepienia w nawie północnej są uboższe niż w nawie południowej. Wyróżnić tu można: gwiaździste (1514 r.) oraz kryształowe z owalną kopułą zakończoną latarnią (1712 r.). Tylko w sklepieniu gwiaździstym został zasto- 


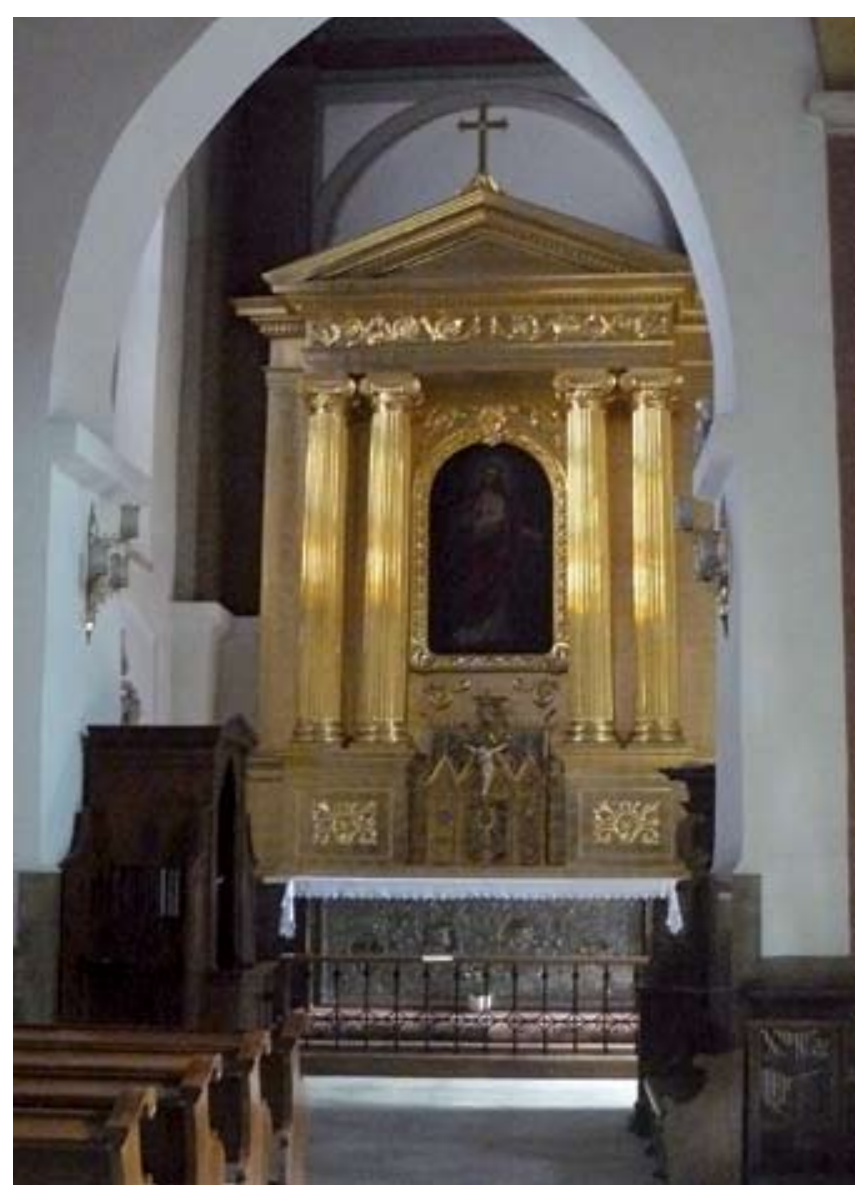

Fig. 10. Ołtarz nawy północnej wykonany z marmuru kararyjskiego, fot. B. Wójcik - The altar of the northern aisle made of the Carrara marble, phot. B. Wójcik

sowany ten sam biały piaskowiec liasowy, co w poprzednio omawianej nawie.

\section{Przedsionek północny}

Przedsionek północny, obecnie Kaplica Martyrologii Polski, połączony jest $\mathrm{z}$ nawą północną ostrosłupowym przejściem, które jest wykończone zabytkowym portalem gotyckim, wykonanym $\mathrm{z}$ drobnoziarnistego piaskowca istebniańskiego (Fig.2, nr 15). Sam przedsionek jest z cegły i kamienia. Ten ostatni został zastosowany w ołtarzu, obramieniach okiennych, posadzce oraz w sklepieniu. Połączenie dwóch materiałów budowlanych sprawia, że ta część Katedry cechuje się bardzo surowym i minimalistycznym stylem (Fig. 13).

Stół ofiarny budują trzy bloki piaskowca istebniańskiego o dłutowanej fakturze nieregularnej. Jest to ten sam piaskowiec, który zastosowano w portalu wejściowym lecz o teksturze gruboziarnistej przechodzącej w nierównoziarnistą. W nieregularnych bryłach tego samego kamienia wykute są również boczne rzeźby. Do wykończenia okna użyto dwóch rodzajów drobnoziarnistych piaskowców: istebniańskiego do wykonania parapetu oraz szydłowieckiego, z którego wyrzeźbiono obramienia okienne. Wszystkie elementy są pokryte nawarstwieniem pyłowym.

Posadzka przedsionka północnego wykonana $\mathrm{z}$ odmiany gruzłowatej wapienia dębnickiego współwystępuje z płytkami tuberoidowego wapienia z Morawicy obfitują-

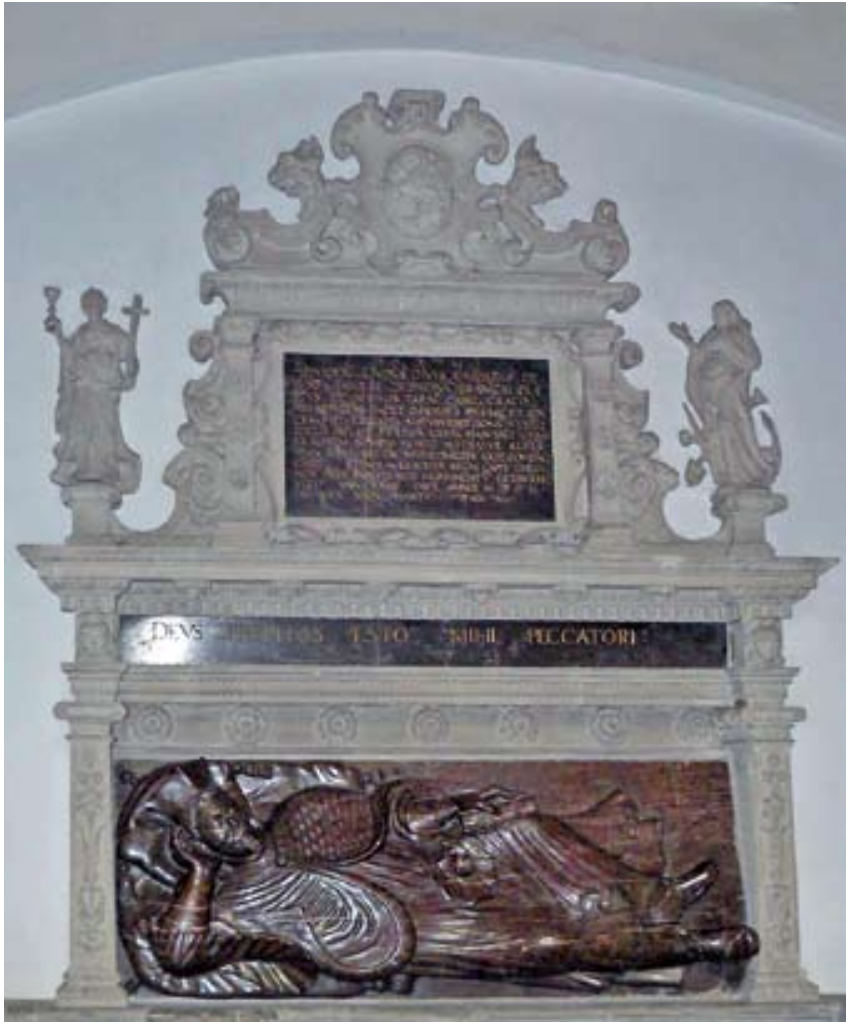

Fig. 11. Pomnik nagrobny ks. Kaspra Branickiego wykonany z wapienia pińczowskiego i czerwonego marmuru włoskiego, fot. B. Wójcik - The sepulchral monument of priest Kacper Branicki made of the Pińczów limestone and a red Italian marble, phot. B. Wójcik

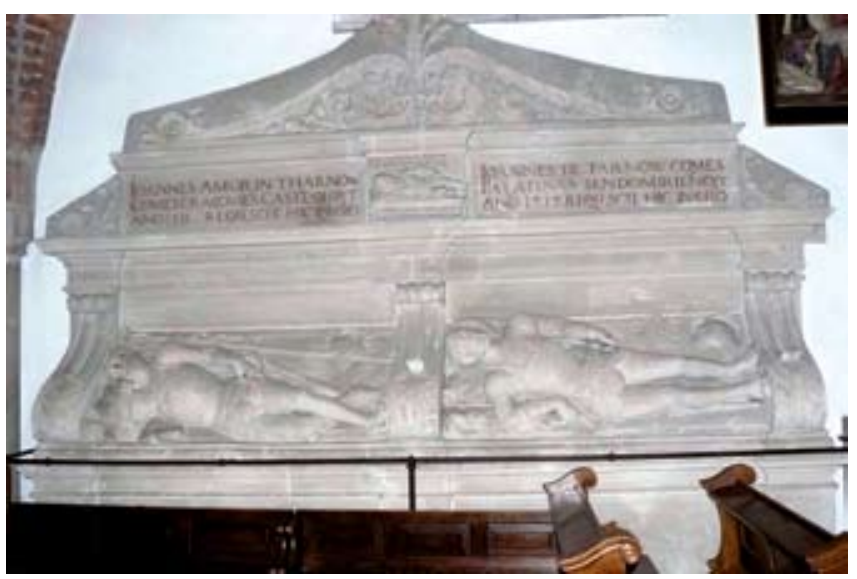

Fig. 12. Pomnik Trzech Janów w nawie północnej wyrzeźbiony w wapieniu pińczowskim, fot. B. Wójcik • The monument of Three Johns in the northern aisle curved in the Pińczów limestone, phot. B. Wójcik

cego w faunę. $Z$ uwagi na różne wykształcenie stan zachowania wapieni jest odmienny. Wapień gruzłowaty ma liczne ubytki i nierówności, co związane jest z jego niejednorodną teksturą. Lepszy stan zachowania przedstawia wapień tuberoidowy. Płytki są równe, a jedyne dające się zauważyć ubytki występują przy szwach stylolitowych. Wszystkie płytki pierwotnie miały fakturę polerowaną, którą z czasem utraciły. Obecnie wapienie są zmatowiałe i przyszarzałe (Fig. 14). 

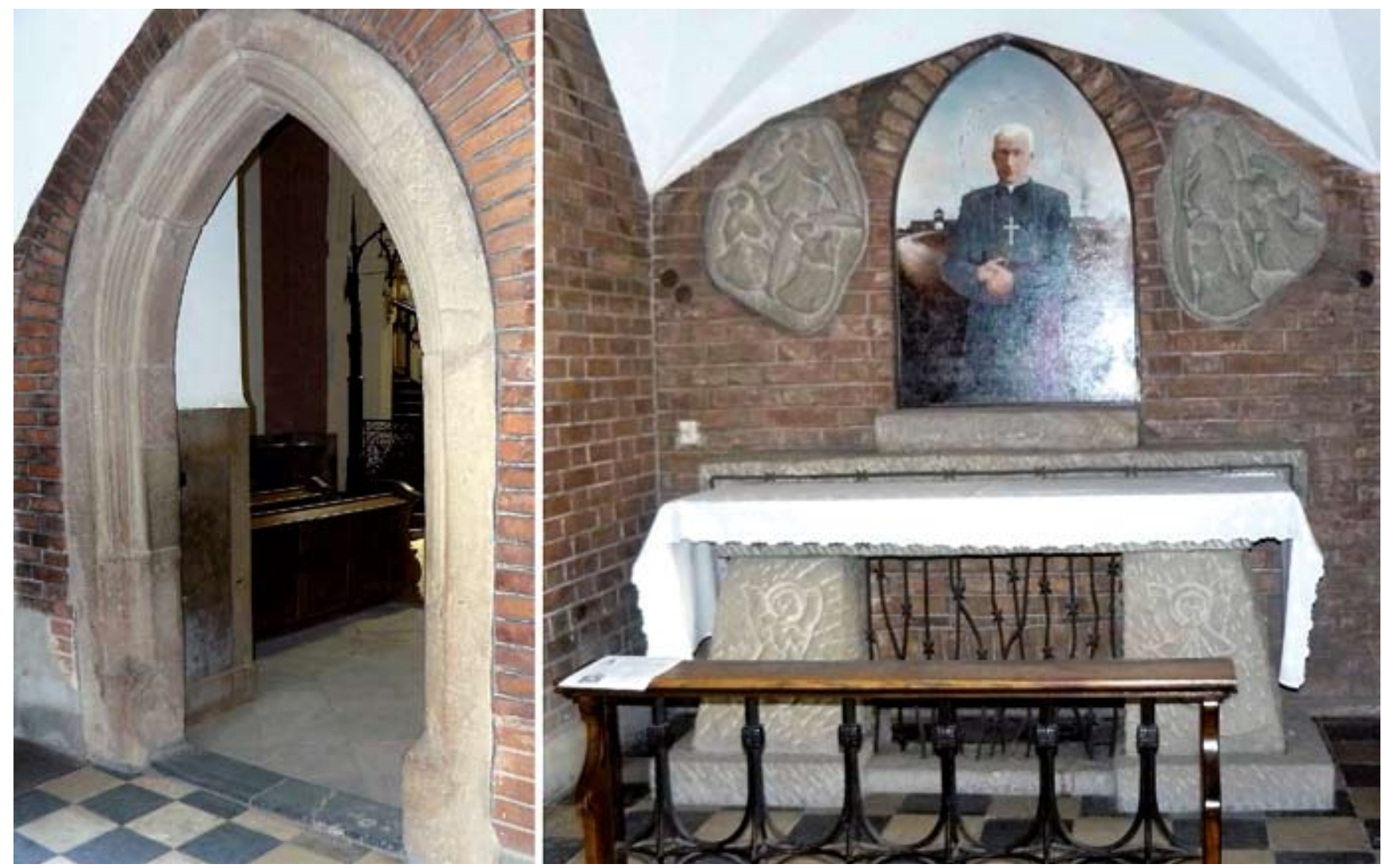

Fig. 13. Portal wejściowy (a) oraz ołtarz (b) wykonane z piaskowca istebniańskiego, fot. B. Wójcik • An inner portal (a) and an altar (b) made of the Istebna sandstone, phot. B. Wójcik

\section{Nawa główna}

Nawa główna katedry (Fig. 2, nr 8-9) stanowi jej najstarszą część. Prezbiterium zdobią figury świętych wykonane z piaskowca liasowego. Rzeźby mają wymiary zbliżone do naturalnych rozmiarów człowieka.

Ozdobą ołtarza głównego są cztery kamienne pomniki grobowe: Ostrogskich, Barbary z Rożnowa, Tarnowskich oraz Zofii Tarnowskiej księżnej Ostrogskiej (Fig. 15). Są one dziełem sztuki o wielkim znaczeniu dla kultury polskiego renesansu i manieryzmu.

Pomnik Ostrogskich, poświęcony Januszowi Ostrogskiemu i jego pierwszej żonie Zuzannie, wykonany jest w czerwonym marmurze włoskim Rosso di Verona oraz w kontrastującym z nim białym alabastrze. Architektura pomnika o wymiarach 12,90 m wysokości oraz 7,90 m szerokości jest renesansowa, natomiast wypełnienie manierystyczne. Czerwony marmur Rosso di Verona podobnie jak użyty w grobowcach nawy południowej, charakteryzuje się obłymi gruzłami wyraźnie odznaczającymi się kolorystycznie od marglisto-żelazistego spoiwa. Jest bardzo dobrze zachowany, co wynika z jego usytuowania wewnątrz Katedry oraz częstej konserwacji. Druga skała zastosowana $\mathrm{w}$ omawianym pomniku to alabaster, stanowiący drobnokrystaliczną odmianę gipsu. Posiada różne odcienie barw od białej, żółtawej, seledynowej po brunatną, a nawet różową. Można go nawet sztucznie zabarwić. Nadaje się doskonale na rzeźby oraz do wyrobu drobnej galanterii (Kozłowski 1986, Sachanbiński 1979).

Do rzeźby gotycko-renesansowego pomnika Barbary z Rożnowa użyto białego drobnoziarnistego piaskowca z Szydłowa. $Z$ tego samego piaskowca wykonano część ar-

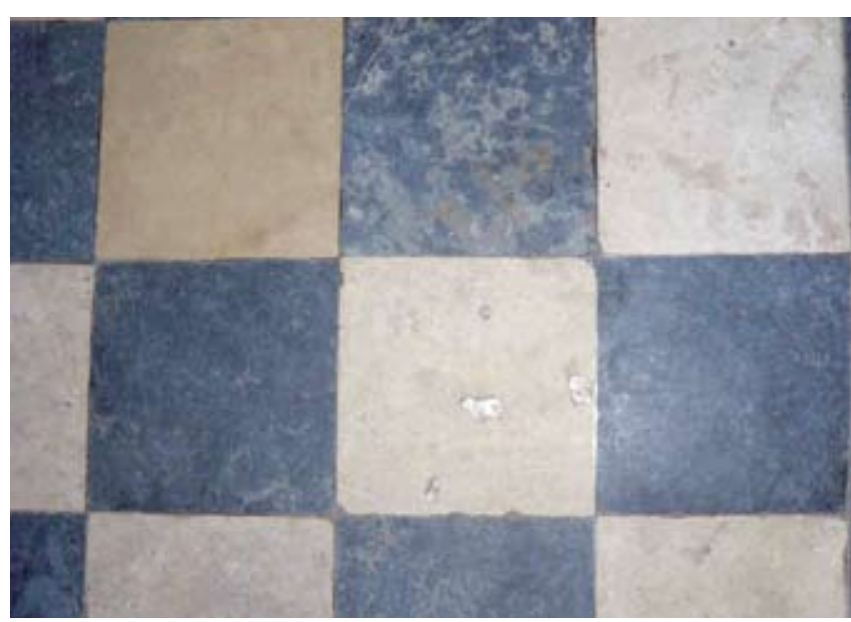

Fig. 14. Posadzka wykonana z czarnego gruzłowatego wapienia dębnickiego i jasno-kremowego wapienia morawickiego, fot. B. Wójcik - The floor made of the black nodular Dębnik limestone and the light creamy Morawica limestone, phot. B. Wójcik

chitektoniczną monumentalnego pomnika Tarnowskich (naprzeciwko pomnika Ostrogskich), upamiętniającego Trzech Janów. Pomnik jest dwukondygnacyjny o wysokości $13 \mathrm{~m}$ oraz szerokości $6,60 \mathrm{~m}$, a jego fasada nawiązuje do frontonu świątyni greckiej. Kolumny, tablice i postacie tego pomnika wykonane są z ciemnoczerwonego marmuru włoskiego Rosso di Verona. Płaskorzeźby natomiast, upamiętniające najdonioślejsze czyny hetmana są alabastrowe.

Pomnik Zofii z Tarnowskich księżnej Ostrogskiej, będący przedłużeniem pomnika Tarnowskich, został wykonany we- 

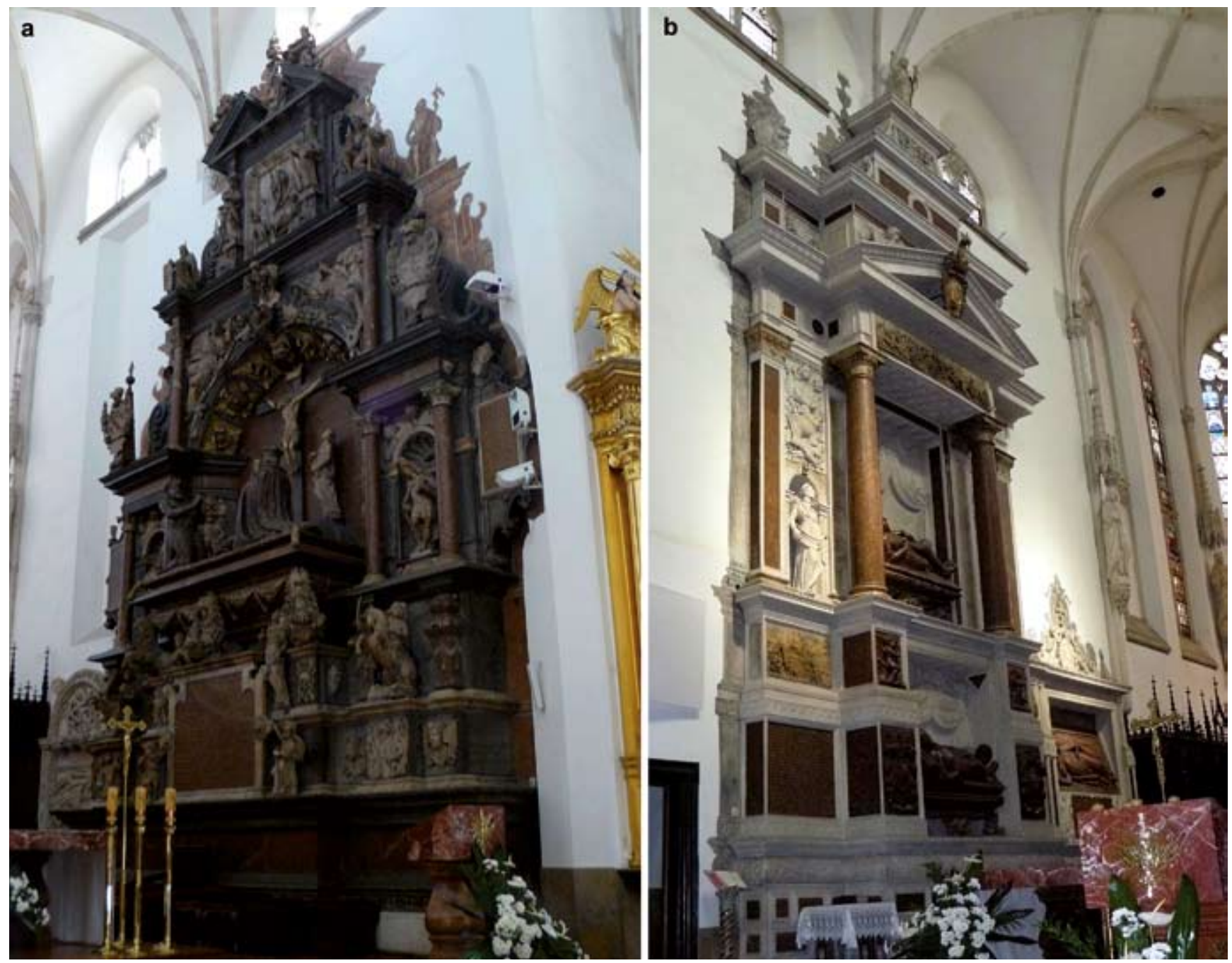

Fig. 15. Pomniki Ostrogskich (a) i Tarnowskich (b) wykonane z marmuru, piaskowca i alabastru na ołtarzu głównym w Katedrze, fot. B. Wójcik - The monuments of the Ostrogski (a) and Tarnowski (b) families made of marble, sandstone and alabaster at the main altar, phot. B. Wójcik

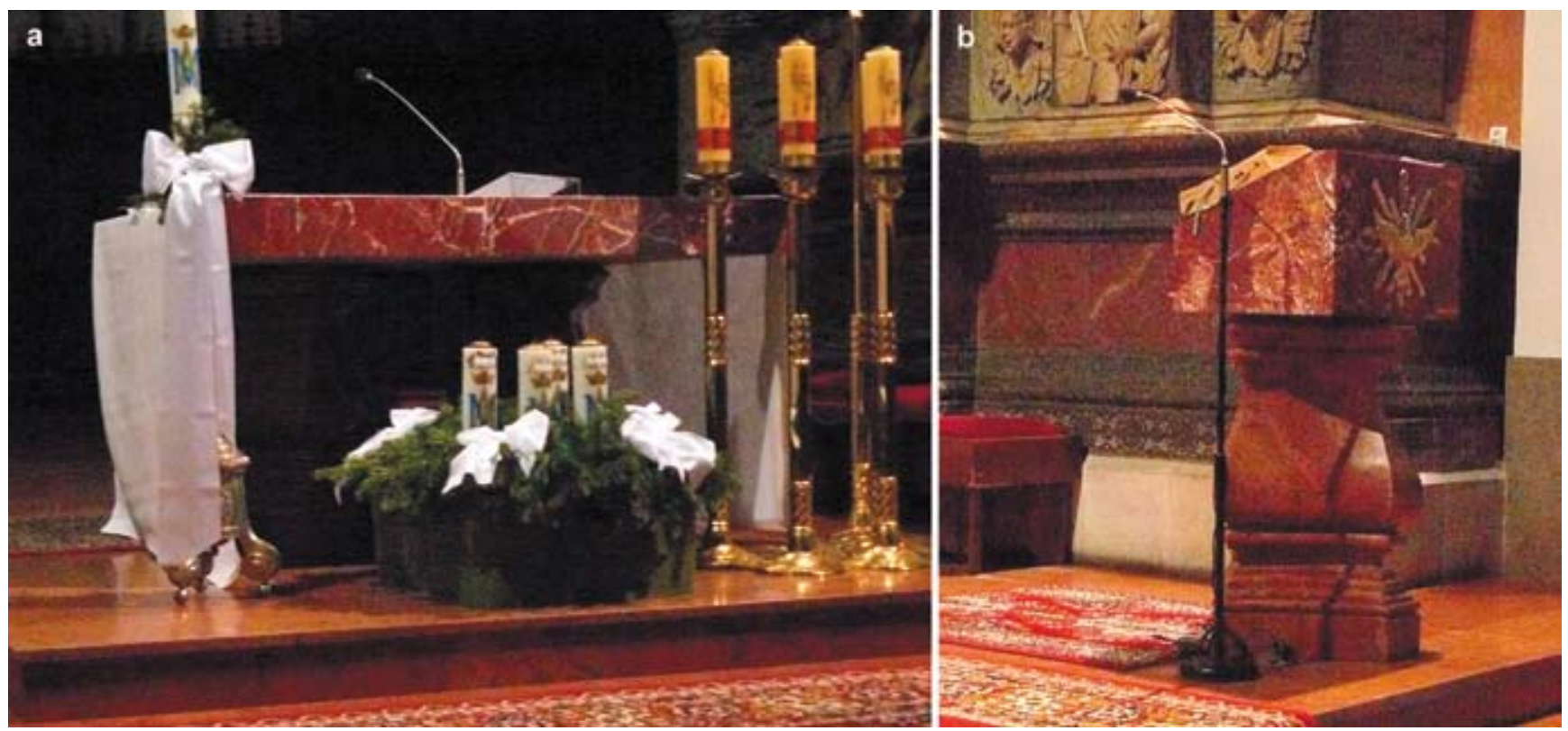

Fig. 16 Stół ofiarny (a) oraz ambona (b) ołtarza głównego w Katedrze wykonane z francuskiego marmuru Red Royal, fot. B. Wójcik • The altar table (a) and the pulpit (b) of the main altar made of the French marble Red Royal, phot. B. Wójcik 

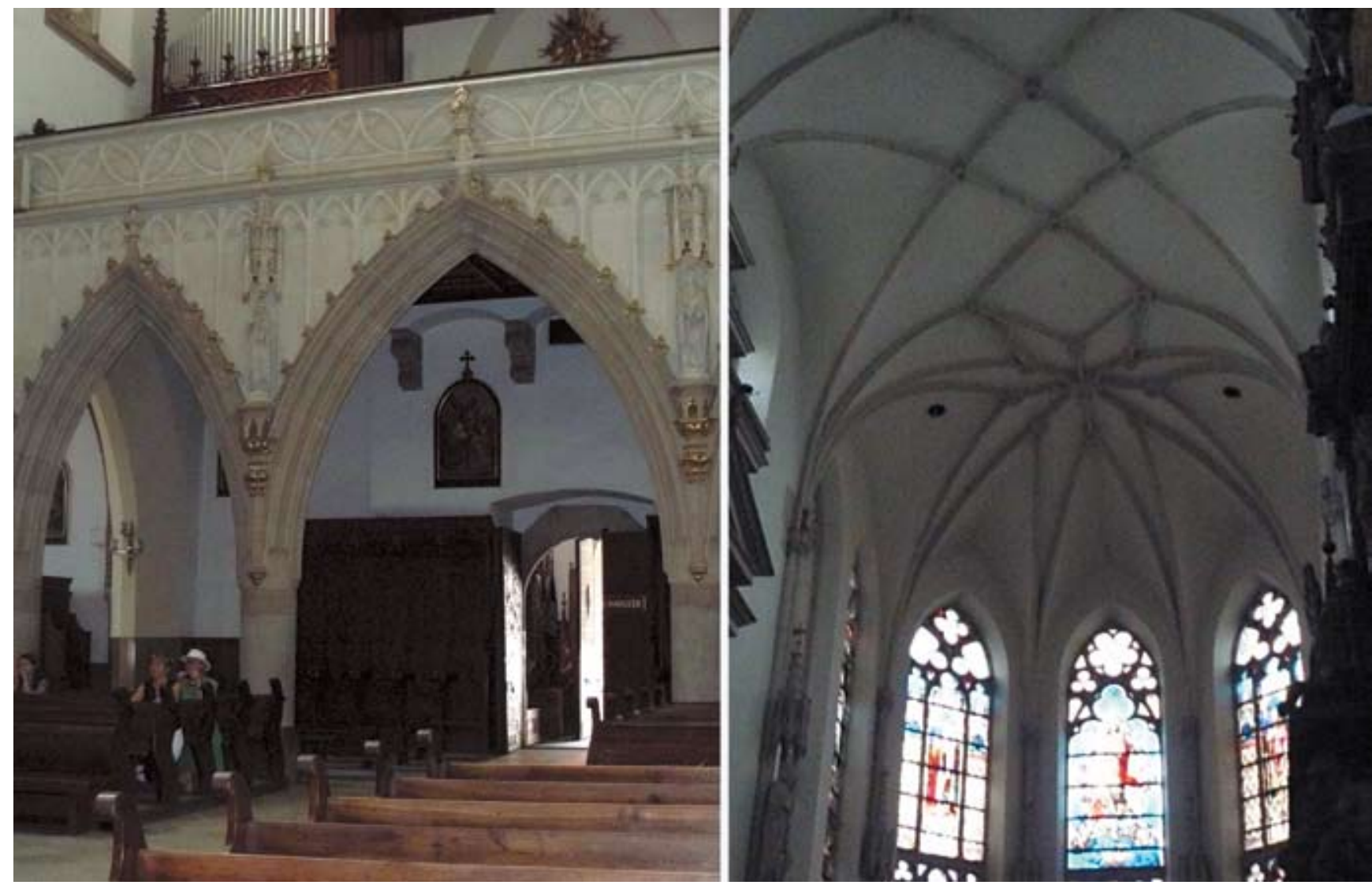

Fig. 17. Łuki gotyckie pod chórem (a) i sklepienia w nawie głównej (b) wykonane z piaskowca liasowego z Szydłowca, fot. B. Wójcik • Gothic arcades under the choir gallery (a) and the vaults of the nave made of the Liassic Szydłowiec sandstone, phot. B. Wójcik

dług pomysłu Padovano w stylu renesansowym również we włoskim marmurze Rosso di Verona.

W centralnej części prezbiterium stoi kamienny stół ofiarny oraz ambona (Fig. 16), wykonane w 1966 roku z marmuru francuskiego Red Royal. Skała ta posiada intensywną wiśniową barwę urozmaiconą obecnością licznych białych żyłek kalcytowych różnie zorientowanych. Żyłki są elementem dekoracyjnym, mogą jednak obniżać parametry kamienia. Są one różnie zorientowane, ich średnia grubość wynosi $0,02 \mathrm{~m}$, a średnia długość $0,15 \mathrm{~m}$.

Posadzkę w prezbiterium zdobi węgierski marmur z Esztergom. Widoczne są w nim nieregularne gruzły utworzone z silnie zwięzłego czerwonego wapienia, które tkwią w nieco jaśniejszym ilasto-żelazistym tle.

W nawie głównej znajdują się dwa neobarokowe ołtarze boczne, pochodzące z 1850 roku, wykonane w pracowni Damasiewicza w Nowym Sączu. Na ołtarzu po lewej stronie umieszczono obraz Matki Bożej Częstochowskiej, pędzla Kazimierza Rydla z Krakowa. Po stronie prawej natomiast znajduje się obraz Pana Jezusa Ukrzyżowanego, wykonany w Kalwarii Zebrzydowskiej przez nieznanego malarza (www.katedra.tarnow.opoka.org.pl). Oba ołtarze ustawione są na postumentach kamiennych z białego marmuru kararyjskiego oraz marmuru „Sławniowice Złociste”. Ten ostatni pochodzący z Dolnego Śląska stanowi kremowo-żółtą odmianę dolomityczną, towarzyszącą szaro-niebieskiej odmianie kalcytowej. Odmiana dolomityczna powstała w wyniku hydrotermalnej dolomityzacji i częściowej sylifikacji marmurów kalcytowych (orogeneza waryscyjska). Ta wła- śnie odmiana użyta została do ozdoby ołtarzy bocznych w formie okładziny pionowej. W marmurze, oprócz dominującego dolomitu, obserwuje się również kwarc, skalenie, biotyt i serycyt. Skała ma strukturę pasiastą, miejscami brekcjową z kawernami, które są częściowo wypełnione skupieniami kwarcu oraz żyłami i gruzłamu kalcytu, rzadziej dolomitu.

Szesnastowieczne łuki gotyckie pod chórem muzycznym oraz elementy dekoracyjne sklepień: sieciowego w prezbiterium i krzyżowo-żebrowego w pozostałej części nawy głównej wykonano, jak w całej Katedrze z piaskowca liasowego z rejonu Szydłowca (Fig. 17).

Posadzkę w całym kościele zdobi polski marmur (odmiana kalcytowa) ze Sławniowic, który makroskopowo ma barwę szaro-niebieską, strukturę zbitą, linijno-równoległą, smużystą, a teksturę średnioblastyczną. Płyty okładzinowe we wnętrzu kościoła wykonane są z polerowanego wapienia plamkowego o barwie beżowej, z licznymi szwami stylolitowymi i amonitami. W miejscach najczęściej użytkowanych płyty poler tracą, a przy szwach stylolitowych tworzą się ubytki.

\section{Kruchta pod wieżą}

Największą ozdobą kruchty jest kamienny portal wewnętrzny zachodnich drzwi wejściowych, pochodzący z początku XVI wieku (Fig. 18). Wykonano go w stylu późnogotyckim z liasowego piaskowca szydłowieckiego. Jest zamknięty półkoliście $z$ obramieniem $z$ gałęzi i herbem Leliwa (Hrycow-Buczyńska, 1991). 


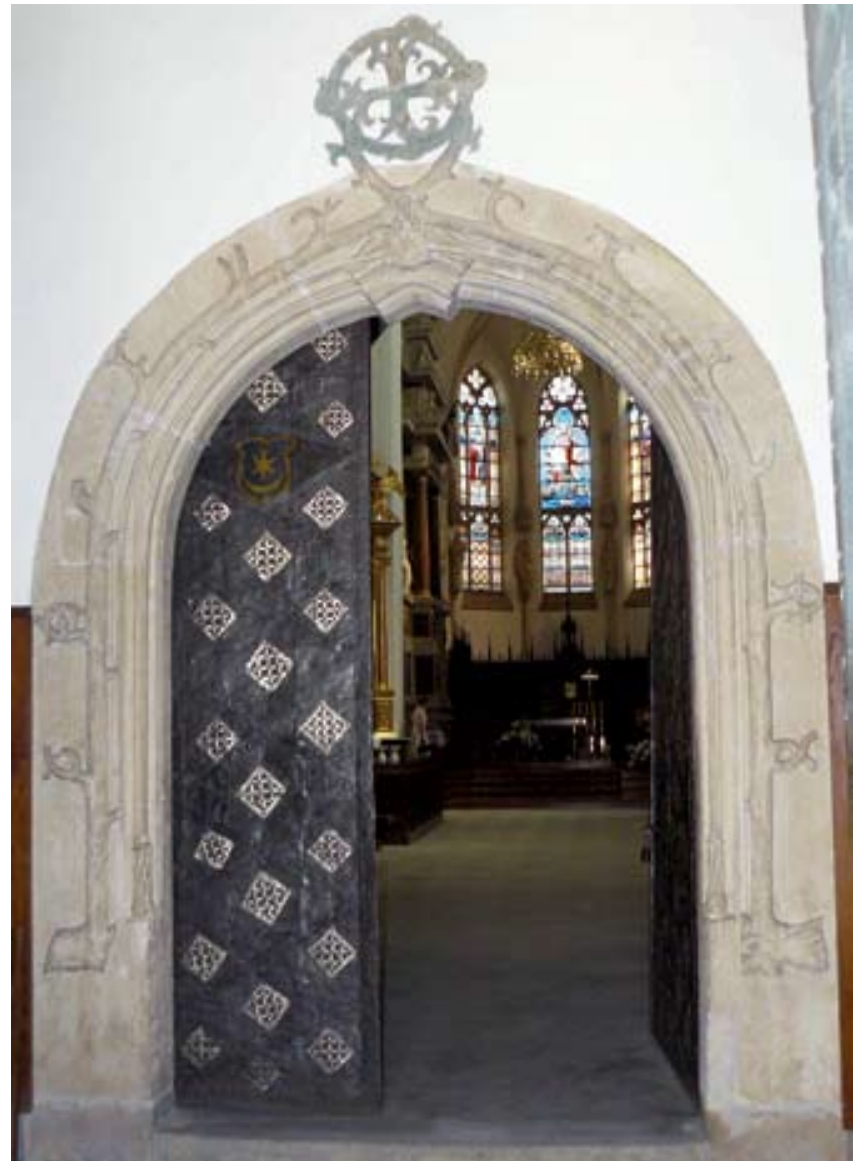

Fig. 18. Zachodni portal wejściowy do Katedry w kruchcie pod wieżą wykonany z piaskowca liasowego z Szydłowca, fot. B. Wójcik - The western inner portal in the narthex under the tower made of the Liassic Szydłowiec sandstone, phot. B. Wójcik).

\section{Podsumowanie}

Niniejszy artykuł miał na celu wyeksponowanie pięknej i zróżnicowanej kamieniarki zastosowanej w zewnętrznym i wewnętrznym wystroju kolegiaty w Tarnowie, która w połączeniu z najważniejszymi elementami architektonicznymi zachęci czytelnika do zwiedzenia tego gotyckiego zabytku. Stwierdzono, że skały zastosowane w kościele pochodzą głównie ze złóż polskich. Najczęściej używano trzeciorzędowego wapienia pińczowskiego i liasowego piaskowca szydłowieckiego, które z uwagi na swe wykształcenie są łatwe w obróbce, a zatem nadają się do rzeźbienia bardzo delikatnych, wręcz finezyjnych i ażurowych form. Do obłożenia cokołu katedry użyto piaskowca istebniańskiego ze złóż znajdujących się na Pogórzu Wiśnicko-Rożnowskim, a więc położonych blisko Tarnowa. Wnętrze kościoła zdobią natomiast skały, które dają się szlifować i polerować, odznaczają się piękną barwą i są bogate w różnego rodzaju elementy dekoracyjne takie jak: szczątki organiczne, plamki, żyłki kalcytowe, czy smugi barwne. Zastosowano tu głównie czarny wapień z Dębnika, z którego wykonano kropielnicę, chrzcielnicę i tablice pamiątkowe, jasnobrunatny wapień z Bolechowic z liczną fauną widoczną na posadzce czy w balustradzie oraz plamkowy wapień z Morawicy użyty jako płyty posadzkowe i pionowe okładzinowe w całym kościele. W mniejszym udziale stosowano marmur ze Sławniowic i alabaster. Zagraniczne marmury (włoski, francuski i węgierski) sprowadzano jedynie do wykonania pomników osób znanych i zasłużonych. Dlatego marmury wloskie można podziwiać jedynie na grobowcach książąt i ich rodzin. W ostatnim 50-leciu dostęp do zagranicznych kamieni stał się łatwiejszy i wtedy użyto marmuru węgierskiego z rejonu Esztergom oraz francuskiego Red Royal do ozdoby prezbiterium.

Zastosowane w kościele skały wykazują różny stan zachowania i charakter zniszczeń, zależny od rodzaju kamienia i jego usytuowania w budowli. Najlepiej materiał kamienny zachował się wewnątrz świątyni co związane jest z jego wyższym stopniem lityfikacji oraz ograniczonym wpływem czynników atmosferycznych. Na zewnątrz natomiast skały (piaskowiec istebniański i wapień pińczowski) poddawane są różnym mechanizmom niszczenia. $\mathrm{W}$ Tarnowie niebagatelną rolę odgrywa emisja zanieczyszczeń z Zakładów Azotowych S.A., które rozpuszczone w wodzie opadowej wnikają w strukturę kamienia doprowadzając do jego destrukcji. Szczególnie podatny na te procesy jest wapień pińczowski. Inne niszczące czynniki to spaliny samochodowe oraz zamróz. $\square$

\section{Summary \\ Let us see the beauty of masonry in the Birth of Holy Virgin Mary collegiate in Tarnów}

\section{Anna Lannik, Anna Smoleńska, Bernadeta Wójcik}

Tarnów came to being in the last years of rule of king Władysław Łokietek (Ladislav the Short) due to colonization initiatives of Spycimir, a Krakow voivode and the progenitor of the Tarnów family line using the Leliwa coat-of-arms (the Leliwites). Due to his efforts, the king granted Tarnów a city charter on $7^{\text {th }}$ March, 1330. The church of the Birth of Holy Virgin Mary was one of the three Tarnów parishes established before 1400. On the $17^{\text {th }}$ April, 1400, Krakow bishop Piotr Wysz, answering the request of Jan of Tarnów, Spicymir's grandson, elevated the parish church standing at the market place to the position of a collegiate church.

Tarnów is currently the second largest town in the Małopolskie voivodeship. Its historic downtown is an attractive part, where some tens of edifices are dated back to the Gothic, Renaissance and Baroque times. Only one of them is Gothic, represented by the most fashionable church in Tarnów, the collegiate of the Birth of Holy Virgin Mary situated at the Cathedral Place. Churches erected in this style are characterized by lightness, high spires and richly ornamented portals.

The Tarnów cathedral has been constructed of bricks with decorative masonry in windows and entrances. It is an oriented edifice built on the plan of an elongated rectangle, with 
a nave with two aisles, an elongated chancel closed by a threesided apse, and with a 72-m tower added from the western side carrying a crown placed in 1898 . There are three direct entrances into the church from the southern, western and northern sides, the fourth (from N) leads to the vestry. A number of ornamental stones from Polish and foreign deposits can be found in the cathedral, both outside and inside the church.

Having looked from the Cathedral Place, one enjoys the ground course, window frames and other architectonic details executed in the fine-grained Istebna sandstone with a characteristic grey-creamy colour. Beautiful pinnacles, window traceries and the portal of the western narthex have been carved in the light creamy Pińczów limestone. The steps of the entrances have been made of the Strzegom granite with medium-crystalline texture. Its blocks have been polished and reveal contours of all minerals, which increases decorativeness of the stone.

The southern porch is the most frequently used entrance. It leads to the southern aisle, constructed in the middle of the $19^{\text {th }}$ century of amalgamated (going from the west): the Chapel of the Sending of Apostles, the Chapel of the Holy Cross being a former porch, the Chapel of Our Lady of the Scapular, the Chapel of St. Benedict. The chapels were added starting from the $15^{\text {th }}$ century to the main part of the Cathedral. In the aisle there are two altars: of Our Lady of Sorrow, and a neo-Renaissance of the Holy Sacrament made of the white Italian marble Bianco Carrara Unito C. Our attention should also be paid to the tombstones: of prince Eustachy Sanguszko (made of the same marble), and of priest Marcin Łyczko (made of the light beige Pińczów limestone and the red Italian marble Rosso di Verona.

The north-western porch leads to the northern aisle, made around 1850 by analogue amalgamation of the Chapel of St. Anne, a former porch, and the Chapel of the Holy Relics (mentioned going from the west). In the aisle there are also tombstones of priest Kasper Branicki made of the marble Rosso di Verona and framed with the fine-crystalline Pińczów limestone and of Three Johns (members of the Tarnowski family), sculpted in the same limestone from Pińczów.

The western porch constructed in the $15^{\text {th }}$ century leads to the nave and the north-eastern porch into the vestry, i.e., the oldest parts of the church. Arcades with pointed arches separate the nave from the aisles. An elevated presbytery with the high altar is separated from the part for worshippers by a rood beam, and from the western part of the presbytery there is an organ choir supported by three arches. The latter were built of fine-grained Liassic sandstone, which is well suited to carving construction elements. The presbytery was built in stages in the $15^{\text {th }}$ and $19^{\text {th }}$ centuries. In its added part there are stalls for canons and the sculptures of Polish saints: St. Kazimierz, St. Kinga, St. Wojciech, St. Stanisław of Szczepanów,
Blessed Szymon of Lipnica and St. Jan of Kęty, curved in the Szydłowiec sandstone and placed on pedestals in 1892. The high altar is adorned by four tombstone statues of the Tarnowski family, Zofia née Tarnowska princess Ostrogska, the Ostrogski family and Barbara of Rożnów. The tombstone of the Ostrogski family was carved in the Renaissance style of the red Italian marble Rosso di Verona and a Polish alabaster, whereas the Gothic-Renaissance tombstone of Barbara of Rożnów of the Liassic sandstone. The monumental tombstone of the Tarnowski family (opposite to the Ostrogski family tombstone) has been built in its architectonic part of the Liassic sandstone, whereas the columns, plaques and figures have been carved in the dark red marble Rosso di Verona, and the bas-reliefs in alabaster. The monument of Zofia née Tarnowska princess Ostrogska, which is an extension of the Tarnowski family tombstone, has been executed after Padovano's design in the Renaissance style from the same material as was used in the Tarnowski family tombstone. The stony altar table and the pulpit, both of 1966, have been made of the French marble Red Royal, a tan-coloured rock with many thin, white calcite veins.

The floor of the whole church is covered with small slabs of the Sławniowice marble, with grey-blue colour and massive, linear-parallel, streaky structure. The wall facings have been cut of the beige-grey Morawica limestone with stylolite seams and beautiful ammonites. The facing plates were polished, but the stone looses its polish in places and there are stone losses close to the stylolite seams.

The narthex under the tower at the main western entrance to the cathedral was built in the $15^{\text {th }}$ century, when the tower was restored from damages inflicted in one of church fires. Inside the narthex there is the beautiful $16^{\text {th }}$-century inner portal, sculpted in the Liassic sandstone, leading into the cathedral. The same sandstone was used to curve decorative elements of all the church vaults.

Writing this paper, the authors intended to stress the beauty and the diversified masonry applied in the outer and inner design of the collegiate in Tarnów. The stones used in Gothic, Renaissance and Baroque times were quarried essentially in Polish deposits. Foreign stones were imported only to execute statues of well-known and meritorious people. We hope that all this, combined with the principal architectonic elements, will stimulate a reader to visit this Gothic church.

The stones used in the church construction and ornaments have been preserved to a various degree and their damage is also of a variable character. The best preserved are the stones inside the church as they are better lithified and their exposition to atmospheric factors is obviously limited. The mechanism of damage affecting the stones exposed outdoors differs. Negative impact on the stones has mostly been imparted by dust contamination, rainwater and frost.

\section{Literatura (References)}

Bednarczyk J., Hoffman M., 1989. Wapienie dębnickie. Przewodnik LX Zjazd Pol. Tow. Geol. w Krakowie.

Bromowicz J., 2001. Ocena możliwości wykorzystania skał z okolic Krakowa do rekonstrukcji kamiennych elementów architektonicznych. Gosp. Surowców Mineralnych, 17/1.
Bromowicz J., Magiera J. 2006, Identyfikacja marmuru użytego w sarkofagu Władysława Jagiełły w Katedrze Wawelskiej. Ochrona Zabytków. Warszawa.

Czermiński J., 1960. Rozwój litologiczny serii węglanowej dewonu południowej części Gór Świętokrzyskich. Prace PIG, 30/2. 
Ginalska T., 2001. Tarnów. Miasto z tradycją - otwarte na przyszłość, Tarnów.

Hrycow-Buczyńska L. ,1991. Ośrodek Dokumentacji Zabytków w Warszawie - Karta ewidencyjna zabytków architektury i budownictwa nr A-228, Warszawa.

ICONS, 2006. Interactive Catalogue of Natural Stones. Variograma, Lisbona.

Kozłowski S., 1986. Surowce Skalne Polski, Wyd. Geol., Warszawa.

Łaptaś A., 1982. Sedymentacja utworów węglanowych dewonu środkowego rejonu Dębnika. Studia Geol. Pol., 75.

Łaptaś A., 1989. Dolomity ze Zbrzy. Przewodnik LX Zjazdu Pol. Tow. Geol. w Krakowie, Warszawa.

Penkala B., 1986. Wapienie pińczowskie w zabytkach Krakowa, Krajowa konferencja naukowo-techniczna „Inżynieryjne problemy w odnowie staromiejskich zespołów zabytkowych”, Kraków.
Peszat C., 1964. Litologia jurajskich skał węglanowych między Tokarnią a Chmielnikiem. Acta Geol. Pol., 14/1.

Peszat C., Buczek-Pułka M., 1984. Własności fizyczno-mechaniczne piaskowców istebniańskich. Kwartalnik AGH Geologia, 10/1.

Procyk W., 1998. Marmury królewskie - Zjawisko wietrzenia i problemy konserwacji. Warszawa.

Rajchel J.,2004. Kamienny Kraków, Spojrzenie geologa, Kraków.

Sachanbiński M., 1979. Kamienie szlachetne i ozdobne Śląska. Ossolineum, Wrocław.

Skoczylas-Ciszewska K., Kamieński M., 1959. O facji innoceramowej warstw istebniańskich pogórza Wiśnicko-Rożnowskiego. Kwart. Geol. 3.

www.katedra.tarnow.opoka.org.pl 